\title{
Seismic Recurrence Intervals and Timing of Aseismic Subduction Inferred From Emerged Corals and Reefs of the Central Vanuatu (New Hebrides) Frontal Arc
}

\author{
FREDERICK W. TAYLOR \\ Institute for Geophysics, The University of Texas at Austin \\ R. LAWRENCE EDWARDS ${ }^{1}$ AND G. J. WASSERBURG \\ Lunatic Asylum of the Charles Arms Laboratory, Division of Geological and Planetary Sciences, \\ California Institute of Technology, Pasadena

\section{CLIFF FROHLICH}

Institule for Geophysics, The University of Texas at Austin

\begin{abstract}
The recognition and dating of corals that have been killed by tectonic uplift allow us to date paleoseismic uplifts in the Vanuatu island arc. We recognize corals that record paleouplifts by their similarity to those known to have died during contemporary sudden uplifts and date them (1) by counting annual coral growth bands (only if part of the coral is alive at the time of collection) or (2) by newly developed techniques for obtaining ${ }^{230} \mathrm{Th}$ ages by mass spectrometry. The mass spectrometric method produces isotopic ages with precisions of \pm 3 to \pm 9 years $(2 \sigma)$ in the $0-1000$ years B.P. time range. The ${ }^{230}$ Th ages in this time range appear to be accurate. Samples whose ages are known by counting coral growth bands give ${ }^{230} \mathrm{Th}$ ages that are indistinguishable from their growth band ages. By dividing the average increment of uplift for the latest Holocene uplifts by the mean Holocene uplift rate, we can estimate average seismic uplift recurrence intervals for the past 6000 years. The results for each of four central Vanuatu arc segments are (1) North Santo emerged $1.2 \mathrm{~m}$ in 1866 A.D. and $0.6 \mathrm{~m}$ 107 years later in 1973 A.D. The average coseismic uplift of $0.9 \mathrm{~m}$ and mean Holocene uplift rate of $4.3 \mathrm{~mm} \mathrm{yr}^{-1}$ suggest a longer recurrence interval of 212 years. (2) South Santo emerged $0.29 \mathrm{~m}$ in 1946 and $0.26 \mathrm{~m} 19$ years later in 1965, including the related 1971 event. Here the mean Holocene uplift rate is $5.5 \mathrm{~mm} \mathrm{yr}^{-1}$. The uplift data suggest a longer average recurrence interval of about 51 years. (3) North Malekula emerged $1.23 \mathrm{~m}$ near 1729 A. D. and $1.05 \mathrm{~m} 236$ years later in 1965 . The mean Holocene uplift rate of $2.7 \mathrm{~mm} \mathrm{yr}$ and mean coseismic uplift of $1.14 \mathrm{~m}$ for dated events suggest a longer recurrence interval of 422 years. (4) Part of southernmost Malekula has uplifted continuously or episodically by about $0.35 \mathrm{~m}$ from about 1957 until at least mid-1983 A.D. The maximum uplift of $2.7 \mathrm{~mm} \mathrm{yr}^{-1}$ occurs near a nest of small earthquakes. Both the earthquakes and rapid uplift suggest that interplate slip beneath south Malekula may be continuous, rather than episodic. Episodes of $0.35 \mathrm{~m}$ uplift would have to recur every 130 years to maintain the $2.7 \mathrm{~mm} \mathrm{yr}^{-1}$ uplift rate. In contrast, we find no evidence of interseismic vertical movements for the other three blocks. The most reasonable interpretation of these results is that the seismic recurrence intervals and processes for accommodation of slip are quite different on adjacent arc segments. We have used the most widely accepted momentmagnitude relationship to evaluate the accumulated seismic slip caused by large earthquakes occurring since 1920. In all four arc segments this analysis suggests that the seismically radiated moments account for less than one-third to one-tenth of the slip associated with plate convergence. The similarity between the paleoseismic record of uplifts and the contemporary record of coseismic uplifts suggests that this analysis can be generalized to times before 1920 . For the northem three segments of central Vanuatu, aseismic slip probably occurs in the same years as large earthquakes because the contemporary coral record records uplifts only in years having large historic earthquakes. This suggests that aseismic slip is not continuous and does not occur at rates which vary slowly over the course of the earthquake cycle. The south Santo segment may have the highest proportion of seismic slip because the mean recurrence interval of 51 years is shortest and the mean Holocene uplift rate of at least $5.5 \mathrm{~mm} \mathrm{yr}^{-1}$ is the fastest.
\end{abstract}

\section{INTRODUCTION}

This paper is the result of ongoing efforts aimed at understanding the nature of crustal movement in the central Vanuatu Arc. The purpose of this work is (1) to present an

INow at Department of Geology and Geophysics, School of Earth Sciences, University of Minnesota, Minneapolis.

Copyright 1990 by the American Geophysical Union.

Paper number 89JB01266.

$0148-0227 / 90 / 89 \mathrm{JB}-01266 \$ 05.00$ overview of new and existing data [Taylor et al., 1981, 1987; Edwards et al., 1988] on the dates and amounts of uplifts recorded by emerged reef corals and (2) to discuss the constraints these data place on the nature and timing of crustal movement in this area.

The amounts of uplift are from measurements of the altitudes of fossil corals killed by discrete emergence events which we assume to be associated with large earthquakes. The dates are determined from coral growth bands in recently emerged corals [Taylor et al., 1981, 1987] and from mass spectrometric ${ }^{230}$ Th ages [Edwards et al., 1987a, b, c, 1988; Edwards, 1988] of older fossil corals. Thus we base our study 
TABLE 1. Mass Spectrometry $230 \mathrm{Th} / 234 \mathrm{U}$ Ages for Coral Samples

\begin{tabular}{|c|c|c|c|c|c|c|c|}
\hline $\begin{array}{c}\text { Field } \\
\text { Sample }\end{array}$ & $\begin{array}{c}\text { Coral } \\
\text { Species }^{a}\end{array}$ & $\begin{array}{c}{ }^{238} \mathrm{U}, \\
\mathrm{nmol} / \mathrm{g}\end{array}$ & $\begin{array}{l}{ }^{232} \mathrm{Th}^{b} \\
\mathrm{pmol} / \mathrm{g}\end{array}$ & $\delta^{234} \mathrm{U}(0),{ }^{c}$ & {$\left[{ }^{230} \mathrm{Th} /{ }^{238} \mathrm{U}\right] \mathrm{act}$} & $\begin{array}{c}\text { Age }^{e} \\
\text { years before } \\
1986\end{array}$ & $\begin{array}{l}{ }^{230} \mathrm{Th} \text { Dates } \\
\text { of Coral Growth } f \\
\text { years A.D. or B.C. }\end{array}$ \\
\hline
\end{tabular}

North Santo: Samples With Ages Known Precisely From Coral Growth Bands

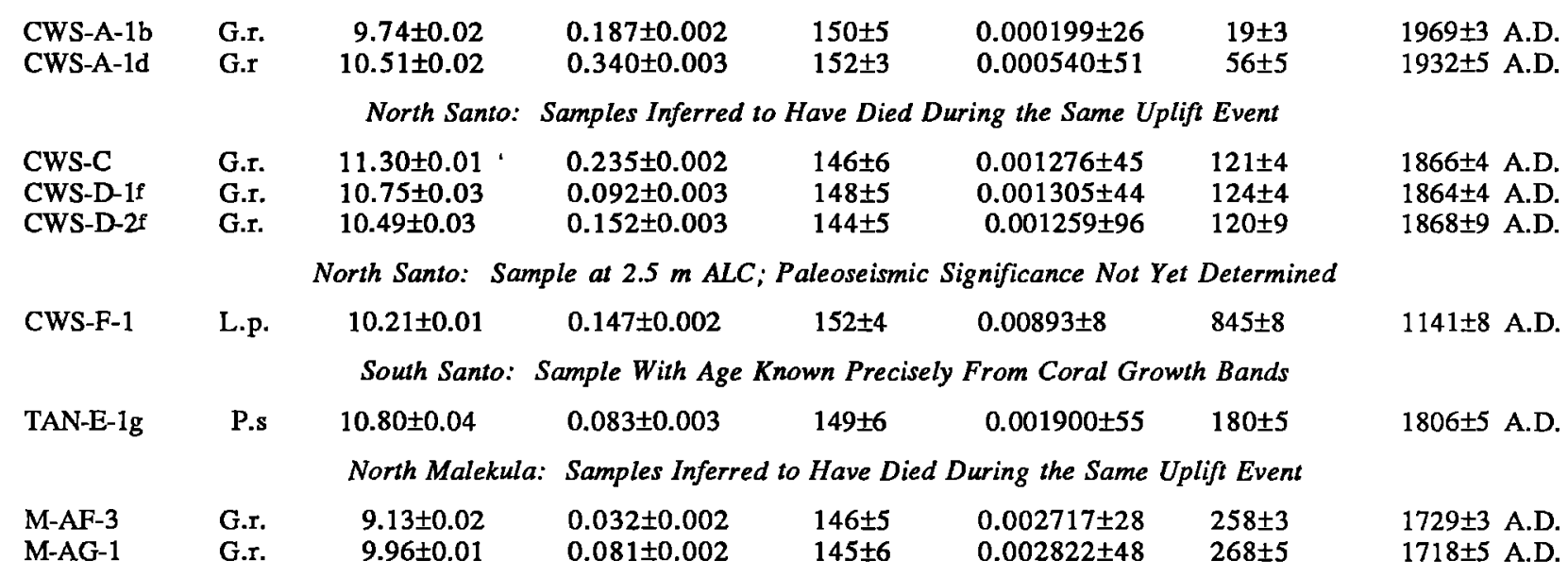

North Malekula: Sample From Near the Top of the Holocene Terrace.

\begin{tabular}{llllllll} 
M-Y-2 & F.sp & $10.53 \pm 0.02$ & $0.047 \pm 0.002$ & $148 \pm 4$ & $0.06332 \pm 17$ & $6162 \pm 25$ & $4174 \pm 25$ \\
\hline
\end{tabular}

Edwards et al., [1988].

${ }^{a}$ Coral species abbreviations: G.r., Goniastrea retiformis; L.p., Leptoria phrygia; P.s., Platygyra sinensis; F. sp., Favia species.

${ }^{b}$ Corrected for analytical blank of $0.02 \pm 0.01$ pmol; most of the error is due to uncertainty in the blank correction.

${ }^{c} \delta^{234} \mathrm{U}(0)=\left[\left({ }^{234} \mathrm{U} /{ }^{238} \mathrm{U}\right)\left(\lambda_{234} / \lambda_{238}\right)-1\right] \times 10^{3} ; \lambda_{234}=2.835 \times 10^{-6} \mathrm{yr}^{-1}$ [Lounsbury and Durham, 1971; DeBievre et al., 1971]; $\lambda_{238}=1.551 \times 10^{-10} \mathrm{yr}^{-1}$ [Jaffey et al., 1971]; the initial uranium isotopic composition [ $\delta 234 \mathrm{U}(\mathrm{T})$ ] is identical to the measured uranium isotopic composition $\left[\delta^{234} U(0)\right]$ for all samples except for M-Y-2 which has $\delta^{234} U(T)=151 \pm 4$.

${ }^{d}\left[{ }^{230} \mathrm{Th} /{ }^{238} \mathrm{U}\right]$ act $=\left({ }^{230} \mathrm{Th} /{ }^{238} \mathrm{U}\right)\left(\lambda_{230} / \lambda_{238}\right) ; \lambda_{230}=9.195 \times 10^{-6} \mathrm{yr}^{-1}\left[\right.$ Meadows et al., 1980] and the value for $\lambda_{238}$ is given in footnote $c$.

'Age at the time of analysis (June 1986 to July 1987); calculated using equation (1) of Edwards et al. [1988].

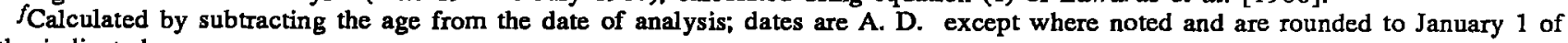
the indicated year.

8CWS-D-1 and CWS-D-2 are replicate analyses of adjacent fragments of the same sample.

on the ability (1) to recognize emerged fossil corals that represent discrete paleoseismic uplifts and (2) to date precisely such corals either by their annual growth bands or by mass spectrometric analyses. These isotopic ages (Table 1) have precisions of $\pm 3-9$ years $(2 \sigma)$ for ages from 0 to 1000 years B.P. and \pm 25 years for ages in the 5000 years B.P. time range. These ages are significantly more precise than ${ }^{14} \mathrm{C}$ ages or ${ }^{230} \mathrm{Th}$ ages determined by alpha spectrometry. The ages also appear to be accurate; coral growth band ages are virtually identical to dates obtained by mass spectrometer ${ }^{230} \mathrm{Th} /{ }^{234} \mathrm{U}$ methods for the same samples [Edwards, 1988; Edwards et al., 1988] (Table 2). By combining these two methods, we directly measure the intervals between large shallow earthquakes causing frontal arc uplift in central Vanuatu (Table 3). In addition, we estimate longer-term average recurrence intervals by using the mean of the increment of uplift associated with individual earthquakes and the mean uplift rate over the past 6000 years. These paleoseismicity data are valuable both for forecasting the probability of future earthquakes and for quantitatively evaluating the nature of the subduction process at the central Vanuatu arc.

Several hundred meters of frontal arc uplift in central Vanuatu may be caused by subduction of the aseismic
d'Entrecasteaux ridge (DR) (Figure 1). DR subduction appears to produce significant structural and morphological changes across the entire frontal and back arcs [Collot et al., 1985; Taylor et al., 1985, 1987]. For example, Taylor et al. [1980, 1987] found that the frontal arc at Santo and Malekula is divided into at least four arc segments: (1) north Santo (NS), (2) south Santo (SS), (3) north Malekula (NM), and (4) south Malekula (SM) (Figure 1). It appears that the arc segment boundaries are strongly influenced by the geometry of DR subduction (Figure 1).

By adding the estimated seismic moments of the large thrust-type interplate earthquakes that have occurred since 1920, we can estimate the proportions of total plate convergence accommodated as seismic and aseismic slip over this time period. Each arc segment has a semi-independent late Quaternary uplift history, coseismic uplift pattern, and, as we shall demonstrate, pattern of seismic recurrence. For all four arc segments of central Vanuatu, our estimates find that less than one-third to one-tenth of the plate convergence is accommodated by earthquakes occurring since 1920 (Table 4). We will show that the paleoseismic record of uplift is similar to the contemporary record of coseismic uplifts indicating that a similar conclusion is valid for the period before 1920 . 
TABLE 2. Comparison of Conventional ${ }^{14} \mathrm{C}$ Ages, ${ }^{14} \mathrm{C}$ Ages Corrected to Dendroyears, ${ }^{230}$ Th Mass Spectrometry Ages, and Coral Growth Band Ages for Corals

\begin{tabular}{ccccccc}
\hline Field & Lab & ${ }^{14} \mathrm{C} \mathrm{Age \pm} 2 \sigma$ & ${ }^{14} \mathrm{C} \mathrm{Age}$ & ${ }^{230}$ Th Age $^{c}$ & Coral Growth & Sample \\
Sample & Sample $^{a}$ & $(t 1 / 2=5568$ years $)$ & (Corrected to & $\pm 2 \sigma$, & Band Age, & Altitude \\
& & years B.P & Dendroyears A.D.) & years A.D or B.C. & years A.D. & ALC \\
\hline
\end{tabular}

North Santo: Samples for Comparing Coral Growth Band and Isotopic Ages

\begin{tabular}{|c|c|c|c|c|c|c|}
\hline \multirow[t]{2}{*}{$\begin{array}{l}\text { CWS-A-1b } \\
\text { CWS-A-1d }\end{array}$} & & & & $\begin{array}{l}1969 \pm 3 \\
1932 \pm 5\end{array}$ & $\begin{array}{l}\text { A.D. } \\
\text { A.D. }\end{array}$ & $\begin{array}{r}1970-1973 \\
1935-1937\end{array}$ \\
\hline & \multicolumn{6}{|c|}{ North Santo: Samples Inferred to Have Died During the Same Uplift Event } \\
\hline CWS-C & $\mathrm{TX} 4502$ & $90 \pm 80$ & $\begin{array}{l}1670-1780 \\
1800-1960\end{array}$ & $1866 \pm 4$ & A.D. & \\
\hline $\begin{array}{l}\text { CWS-D-1 } \\
\text { CWS-D-2 }\end{array}$ & & & & $\begin{array}{l}1864 \pm 4 \\
1868+9\end{array}$ & $\begin{array}{l}\text { A.D. } \\
\text { A.D. }\end{array}$ & \\
\hline
\end{tabular}

North Santo: Sample at $2.5 \mathrm{~m}$ ALC; Paleoseismic Significance Not Yet Determined

$\begin{array}{llllll}\text { CWS-F-1 } & \text { TX4501 } & 980 \pm 120 & 780-1010 & 1141+8 & \text { A.D. }\end{array}$

South Santo: Sample for Comparing Coral Growth Band and Isotopic Age

$\begin{array}{llllrr}\text { TAN-E-1g TX4503 } 270 \pm 120 & 1460-1675 & 1806 \pm 5 \text { A.D. } & 1804-1810 \\ & & 1730-1805 & -2.0 \\ & 1930-1960\end{array}$

North Malekula: Samples Inferred to Have Died During the Same Uplift Event

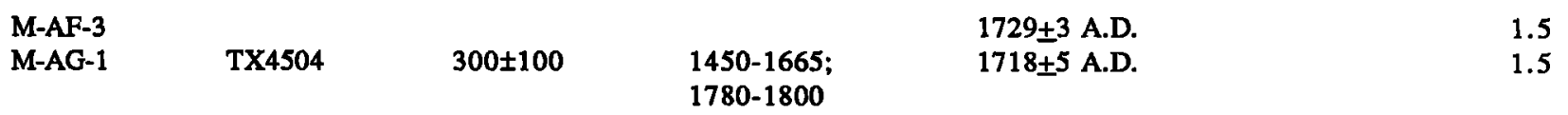

North Malekula: Sample From Near Top of Holocene Terrace

$\begin{array}{lll}\text { M-Y-2 LD1526D } & 4174 \pm 25 \text { B.C. }\end{array}$

$4174 \pm 25$ B.C.

${ }^{a}$ Lab numbers for previous isotopic ages shown in column 3. TX is for The Radiocarbon Laboratory, The University of Texas at Austin. LD is for W. S. Broecker's laboratory at Lamont-Doherty Geological Observatory.

${ }^{b}$ Corrected for changes in the $14 \mathrm{C} / 12 \mathrm{C}$ ratio of the atmosphere with time using the curves of Stuiver [1982]. No corrections have been made for natural fractionation of carbon isotopes or differences between the $14 \mathrm{C} / 12 \mathrm{C}$ ratio of the growth reservoir and the atmosphere.

From Edwards et al. [1988] and Table 1.

${ }^{d} \mathrm{ALC}$ is height of the sample in meters above living coral of the same species.

'CWS- D-1 and CWS-D-2 are replicate analyses of adjacent fragments of the same sample.

The LD ${ }^{230} \mathrm{Th}$ age for this sample is $5600 \pm 1000$ ( $\pm 2 \sigma$ by alpha counting) [Taylor et al., 1980].

In this and previous studies [e.g., Kanamori, 1977; Lay and Kanamori, 1981; Lay et al., 1982], analysis of the seismic moments suggests that the fault slip recorded by radiated earthquake waves corresponds to only a fraction of the slip accompanying plate convergence. Does the remaining aseismic slip occur continually at a constant rate, episodically at rates varying over the course of the earthquake cycle, or only within the hours or days of major earthquakes? In three of the four central Vanuatu arc segments, corals provide no clear evidence of permanent uplift in years having no large earthquakes. Furthermore, the Holocene tectonic uplift pattern does not differ from that expressed by coseismic uplifts occurring since 1920 . Thus we will tentatively infer that in central Vanuatu the aseismic slip generally occurs within the same years as major earthquakes, and probably within hours or days. This assumes that seismic and aseismic slip produce similar amounts and patterns of vertical deformation.

\section{METHODS AND PRINCIPLES}

\section{Determination of the Precise Ages of Uplift Events}

Coral colonies living at the shallowest possible depths (usually intertidal) are partially or completely killed by tectonic emergence of even a few centimeters [Taylor et al., 1981, 1987]. Therefore the age of the the last skeletal material accreted to the dead surface of a tectonically emerged coral records the time of the tectonic event. Using this concept, Taylor et al. [1981, 1987] analyzed the annual growth bands (similar to tree rings) of coral colonies partially killed by tectonic emergence events to determine a record of contemporary uplift in Vanuatu. The largest emergence of about $1.2 \mathrm{~m}$ occurred in 1965 on part of northern Malekula.

In the process of mapping young emerged corals, we discovered higher, dead emerged corals with surfaces that were more weathered than the lower corals (Figure 2). We propose 
TABLE 3. Times Between Dated Uplifts and Mean Holocene Recurrence Intervals Calculated From Uplift Data

\begin{tabular}{|c|c|c|c|c|c|c|c|}
\hline $\begin{array}{c}\text { Dates of } \\
\text { Coseismic } \\
\text { Uplifts, } \\
\text { years A.D. }\end{array}$ & $\begin{array}{l}\text { Times } \\
\text { Between } \\
\text { Dated Uplifts } \\
\text { (yr) } \\
\text { A }\end{array}$ & $\begin{array}{c}\text { Uplift } \\
\text { for Each } \\
\text { Event, } \\
\text { m }\end{array}$ & $\begin{array}{l}\text { Mean } \\
\text { Uplift for } \\
\text { All Events, } \\
\text { m } \\
B\end{array}$ & $\begin{array}{l}\text { Holocene } \\
\text { Terrace } \\
\text { Heights, } \\
\text { m ALC } \\
\text { C }\end{array}$ & $\begin{array}{c}\text { Mean Uplift } \\
\text { Rate Since } \\
6000 \text { year B.P., } \\
\text { mm } / y r \\
D=C / 6000 \text { years }\end{array}$ & $\begin{array}{l}\text { Mean Holocene } \\
\text { Recurrence Interval } \\
\text { From Uplift Rate } \\
\text { and Mean Uplift } \\
E=\text { B/D years }\end{array}$ & $\begin{array}{c}\text { Time Between Dated } \\
\text { Uplifts Versus Mean } \\
\text { Holocene Recurrence } \\
\text { Interval years } \\
A \text { Versus } E\end{array}$ \\
\hline \multicolumn{8}{|c|}{ Olpoy, North Santo } \\
\hline \multirow[t]{2}{*}{$\begin{array}{l}1973 \\
1866\end{array}$} & & $\begin{array}{l}0.59 \\
1.2\end{array}$ & & & & & \\
\hline & 107 & & 0.9 & 25.5 & 4.25 & 212 & 107 vs 212 \\
\hline \multicolumn{8}{|c|}{ Tasmaloum, South Santo } \\
\hline \multirow[t]{2}{*}{$\begin{array}{l}1971 \\
1965 \\
1946\end{array}$} & & $\begin{array}{l}0.06 \\
0.20 \\
0.29\end{array}$ & & & & & \\
\hline & 19 & & 0.28 & 33.0 & 5.5 & 51 & 19 vs 51 \\
\hline \multicolumn{8}{|c|}{ Unmak, North Malekula } \\
\hline $\begin{array}{l}1965 \\
1729\end{array}$ & 236 & $\begin{array}{l}1.05 \\
1.23\end{array}$ & 1.14 & 16.0 & 2.7 & 422 & 236 vs 422 \\
\hline \multicolumn{8}{|c|}{ Benvat, South Malekula } \\
\hline \multirow[t]{2}{*}{$\begin{array}{l}1977-81 \\
1971 \\
1969 \\
1965 \\
1957\end{array}$} & $\begin{array}{l}\text { Taken as one } \\
\text { extended event }\end{array}$ & $\begin{array}{l}0.04 \\
0.05 \\
0.07 \\
0.09 \\
0.10\end{array}$ & $\begin{array}{l}\text { Taken as one } \\
\text { extended event }\end{array}$ & & & & \\
\hline & & & 0.35 & 16.0 & 2.7 & $\geq 130 ?$ & $? \mathrm{vs} \geq 130 ?$ \\
\hline
\end{tabular}

that such corals represent tectonic emergence events older than those that affected coral colonies still living at lower levels. These higher corals are analogous to those killed by contemporary coseismic uplifts because they (1) occur in growth position (e.g., Figure 2) and (2) stand out in relief on the emerged coral reefs. Using a hand level and rod, we measured altitudes of the emerged corals relative to nearby living colonies of the same species. In this paper all sample altitudes are meters above living coral (ALC). We collected coral samples using either a diamond core drill or hammer and chisel.

Note that we have not simply equated discrete terraces with individual coseismic uplift events. Such an interpretation does not appear to be appropriate for central Vanuatu emerged

TABLE 4. Estimated Accumulated Earthquake Moments and Seismic Slip Since 1920 Along the Central Vanuatu Arc

\begin{tabular}{|c|c|c|c|c|c|c|c|}
\hline Segment & $\begin{array}{l}\text { Dates of } \\
\text { Earthquake } \\
\text { Sequences }\end{array}$ & $\begin{array}{r}\text { Estimate } \\
\text { Mon } \\
\text { dyne cr } \\
M_{0} \text { min }\end{array}$ & $\begin{array}{l}\text { d Seismic } \\
\text { nent, }{ }^{a} \\
\frac{n \times 10^{25}}{M_{0} \max }\end{array}$ & Sources $^{a}$ & $\begin{array}{c}\text { Length } L \text { and Width } W \\
\text { of Fault Segment }^{b} \\
\text { km }\end{array}$ & $\begin{array}{c}\text { TotalSeismic } \\
\text { Slip, }^{c} \\
\mathrm{~cm}\end{array}$ & $\begin{array}{l}\text { Fraction of Total } \\
\text { Slip Since } 1920, d \%\end{array}$ \\
\hline $\begin{array}{l}\text { North } \\
\text { Santo }\end{array}$ & $1973^{e}$ & 253 & 304 & $\begin{array}{l}\text { C\&I, } \\
\text { S }\end{array}$ & $100 \times 115$ & $39-47$ & $\sim 8$ \\
\hline $\begin{array}{l}\text { South } \\
\text { Santo/ } \\
\text { North } \\
\text { Malekula }\end{array}$ & $\begin{array}{l}1946 e^{e} \\
1965, e^{e} 1971\end{array}$ & 208 & 808 & $\begin{array}{l}\text { C\&I, } \\
\text { E, S }\end{array}$ & $100 \times 80$ & $46-180$ & $8-32$ \\
\hline $\begin{array}{l}\text { South } \\
\text { Malekula }\end{array}$ & 1927 & 56 & 56 & $\mathbf{S}$ & $60 \times 70$ & 24 & 4 \\
\hline
\end{tabular}

'Minimum and maximum estimates of seismic moment are smallest and largest moments reported by $\mathrm{E}$ [Ebel, 1980], C\&I [Chinn and Isacks, 1983], or $S$ which is determined from available reported surface wave magnitudes using the relation of $H a n k s$ and Kanamori [1979]. When earthquake sequence includes more than one event, the moment values in the table are sums for all major events in the sequence.

${ }^{b} \mathrm{~L}$ is along-strike length of arc segment; $W$ is approximate dimension of aftershock zone as reported by lsacks et al. [1981].

Fraction is $\mathrm{s} / 570 \mathrm{~cm}$, which assumes that there has been convergence of $10 \mathrm{~cm} \mathrm{yr-1}$ between 1920 and $1987 \mathrm{~A}$. D.

${ }^{d}$ Slip $s$ is $M_{0} / \mu A$, where rigidity $\mu=5.6 \times 1011 \mathrm{~g} \mathrm{~cm}^{-1} \mathrm{~s}^{-2}$, and $A=L \times W$. The two values in the table are calculated from $M_{0} \min$ and $M_{0} \max$, respectively.

'The 1973 sequence includes a mainshock and one aftershock; the 1965 sequence includes two foreshocks, a mainshock, and two aftershocks; two separate earthquakes occurred in January 1946. 


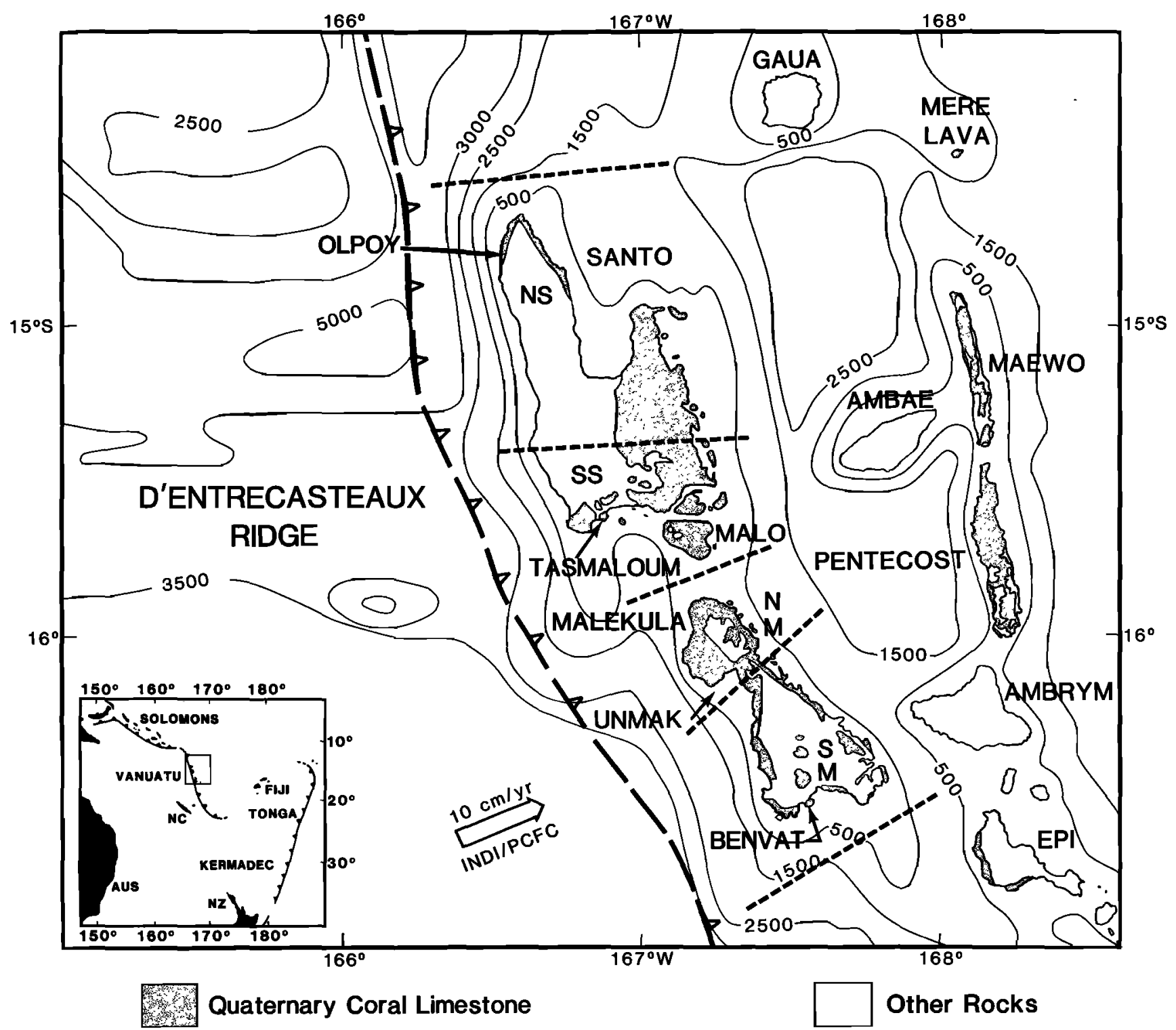

Fig. 1. Map of bathymetry and occurrence of emerged coral limestone versus all other rock types in central Vanuatu. The convergence rate of $10 \mathrm{~cm} \mathrm{yr}^{-1}$ [Minster and Jordan, 1978] does not include the expected contribution from back arc spreading on the Fiji plateau [e.g., Falvey, 1975]. Boundaries between frontal arc segments are taken from Taylor et al. [1980, 1987] and are supported by independent studies including Ebel [1980]. Chatelain et al. [1986] proposed the additional boundary limiting the southem side of the SM (south Malekula) block. Bathymetry after Kroenke et al. [1983].

reefs. Emerged Holocene reefs on parts of Santo and Malekula Islands have as many as six subsidiary terrace levels from sea level to as high as at least $33.5 \mathrm{~m} \mathrm{ALC}$. However, no discrete terrace level formed when the 1965 earthquake sequence caused $1.2 \mathrm{~m}$ of uplift on north Malekula or when the 1973 earthquakes caused $0.6 \mathrm{~m}$ of uplift on north Santo. On north Malekula, free-standing corals on part of a rough seaward sloping coral limestone terrace surface preserve evidence of the 1965 uplift (Figure 2). Additional small uplifts will cause this surface to completely emerge as a discrete terrace representing multiple events. This surface is shared at higher levels by corals that emerged before 1965 and at lower levels by living corals. The highest corals that emerged in 1965 record the highest level of coral growth before the 1965 uplift [Taylor et al., 1980]. The 1965 emerged corals are often sparsely distributed and do not form a continuous surface. Yet, here there are four distinct emerged Holocene terraces reaching from near sea level to about $16 \mathrm{~m} \mathrm{ALC} \mathrm{(Figure} \mathrm{2).} \mathrm{It} \mathrm{is} \mathrm{unlikely} \mathrm{that} \mathrm{discrete}$ coseismic uplift events of several meters each caused these or most other such terraces in central Vanuatu because all documented coseismic uplifts are smaller and do not produce terraces. It is possible that individual larger increments of uplift might form terraces. However, larger-scale terraces in central Vanuatu are more likely the result of a complex interaction of sea level changes, preexisting substrate morphology, coral reef growth, erosion, and possibly variable rates of vertical tectonism.

Before equating terraces with coseismic uplifts, we should have evidence that contemporary uplifts have produced discrete terraces in a particular area. For example, on Middleton Island, Plafker and Rubin [1978] could reasonably 


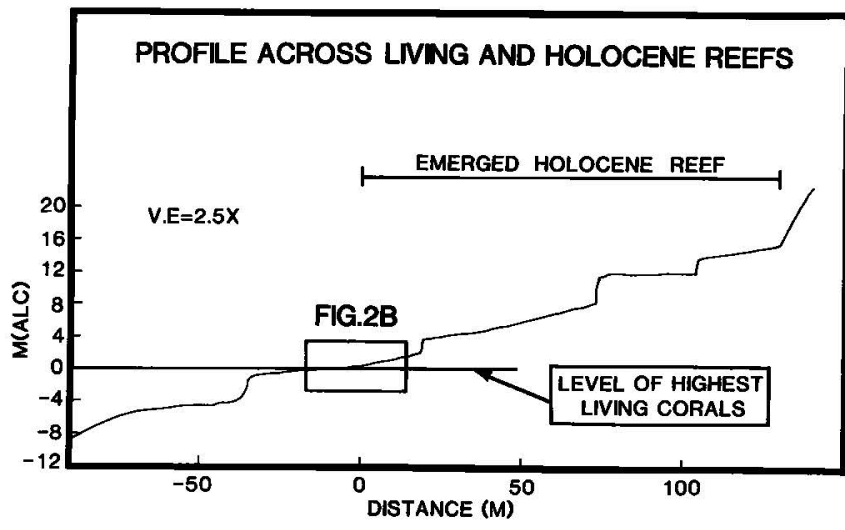

Fig. $2 a$

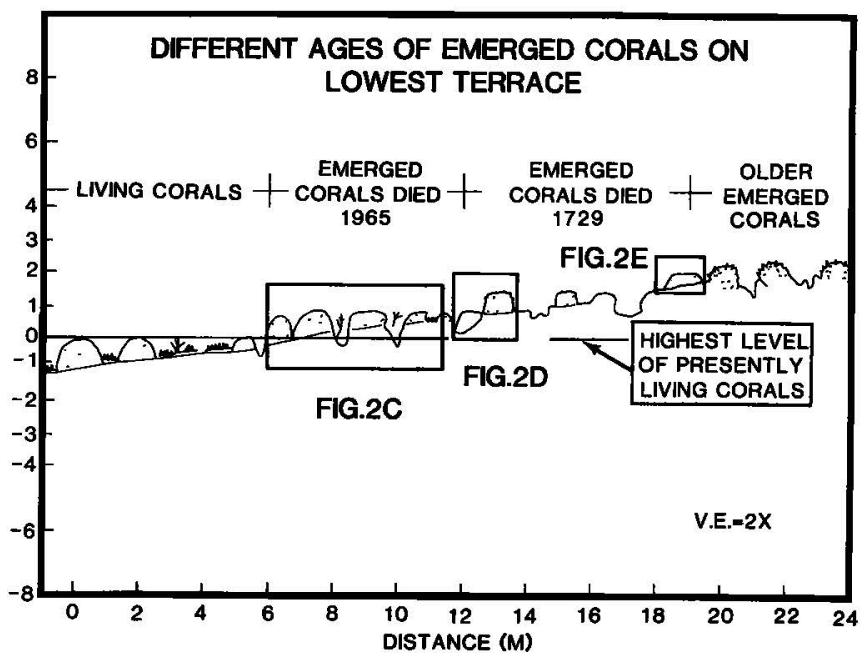

Fig. $2 b$

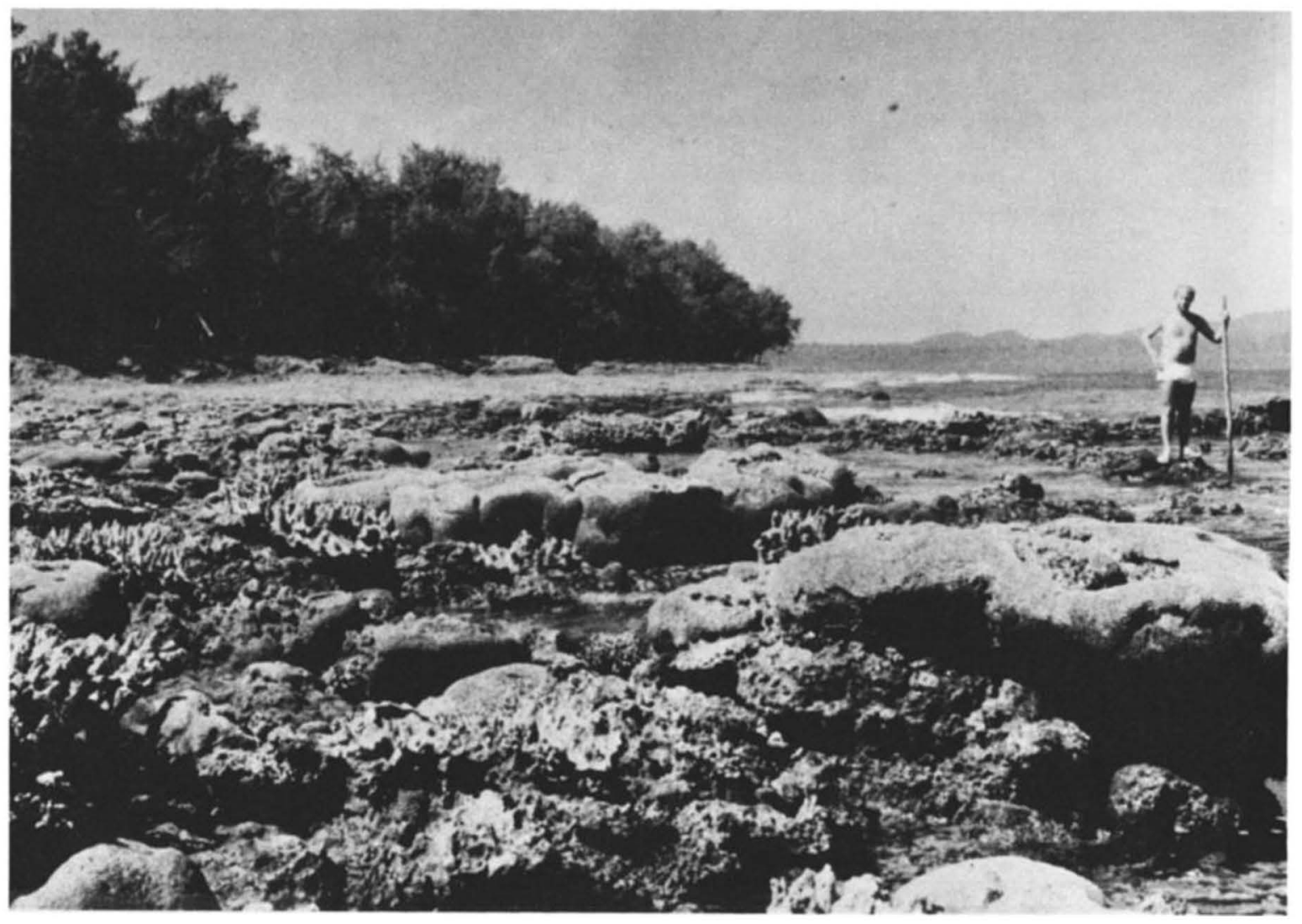

Fig. $2 c$

Fig. 2. Topographic profiles and views of the intertidal and emerged Holocene reef near Unmak village (Figure 1) on north Malekula, Vanuatu. At the largest scale shown (Figure 2a) are several terraces on the emerged Holocene reef limestone which extend farther inland up to a beight of at least $16 \mathrm{~m}$ ALC in this area. Living corals occupy the shallow subtidal reef surface (Figure 2b). Many corals that emerged and died during the 1965 earthquake (Figure $2 c$ ) occur up to $1.05 \mathrm{~m}$ higher than the highest living corals found in channels among the emerged corals as well as seaward. In more detail, Figure $2 d$ shows the upper limit of the 1965 corals and lower exposure of corals that were killed by the most recent pre-1965 uplift. Note the flat-topped morphology of the Goniastrea retiformis coral head that had lived at the shallowest possible depths until it was uplifted during the 1965 earthquake. Figure $2 e$ shows a similar flat-topped emerged G. retiformis coral head about $2.28 \mathrm{~m}$ ALC or $1.23 \mathrm{~m}$ higher than the uppermost 1965 corals. The form and life position of this colony indicate that it emerged and died due to a discrete uplift event just as the uppermost 1965 corals (Figures $2 c$ and $2 d$ ) were killed by coseismic uplift in August 1965 . The ${ }^{250}$ Th ages for samples M-AG-1 and MAF-3 (Tables 1 and 2) indicate that the emerged corals from 1.05 to $2.28 \mathrm{~m} \mathrm{ALC}$ died in 1729 A.D. The similarity in the ${ }^{230}$ Th ages of these two samples indicates that the two corals died at the same time, consistent with the idea that they were killed by coseismic emergence. We found no evidence of an emergence event recorded by corals between the uppermost 1965 corals at $1.05 \mathrm{~m}$ ALC and $2.28 \mathrm{~m}$ ALC. Neither of these two events is clearly recorded by an emerged terrace on the Holocene reef surface. 


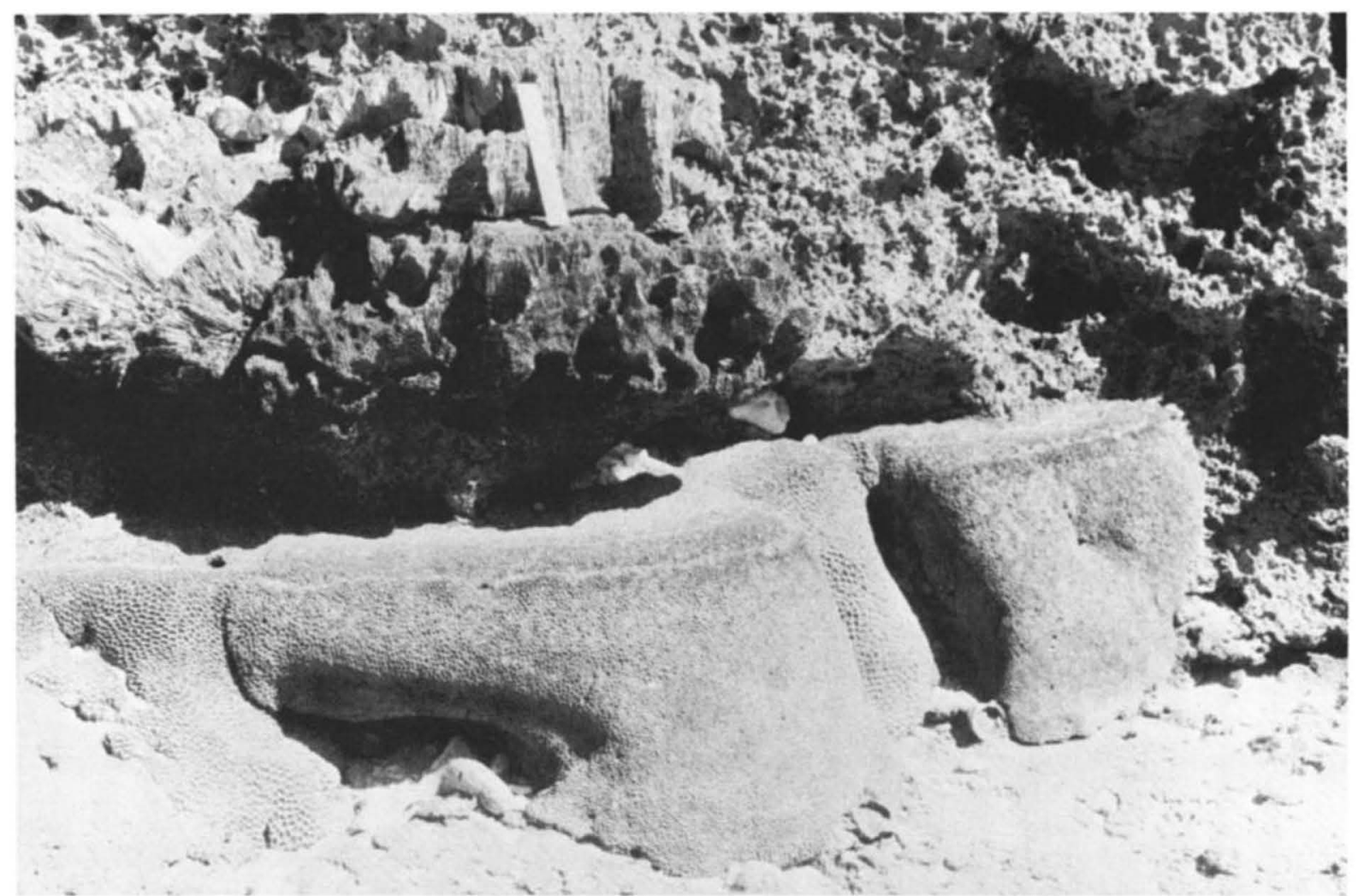

Fig. $2 d$

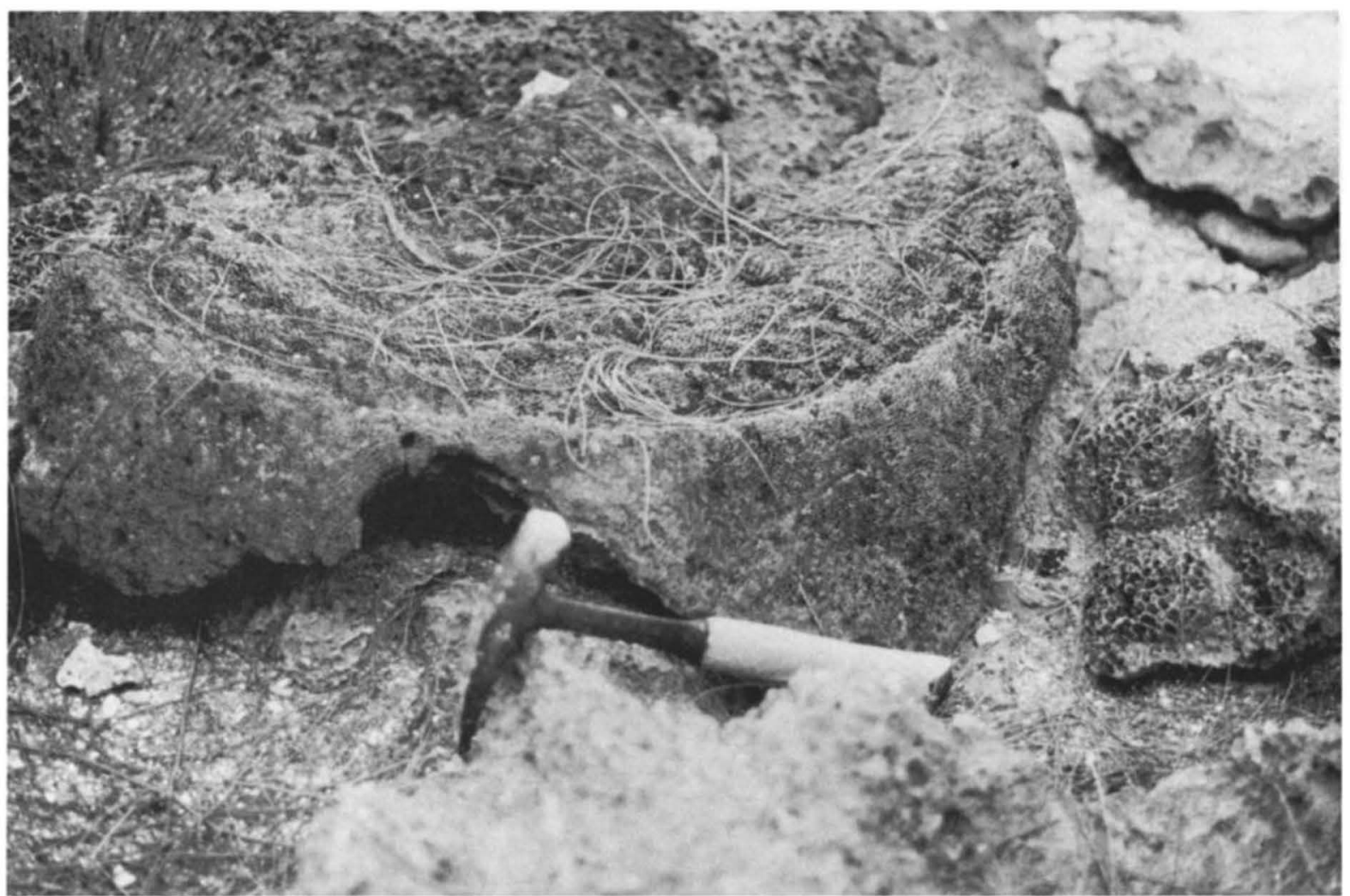

Fig. $2 e$ 


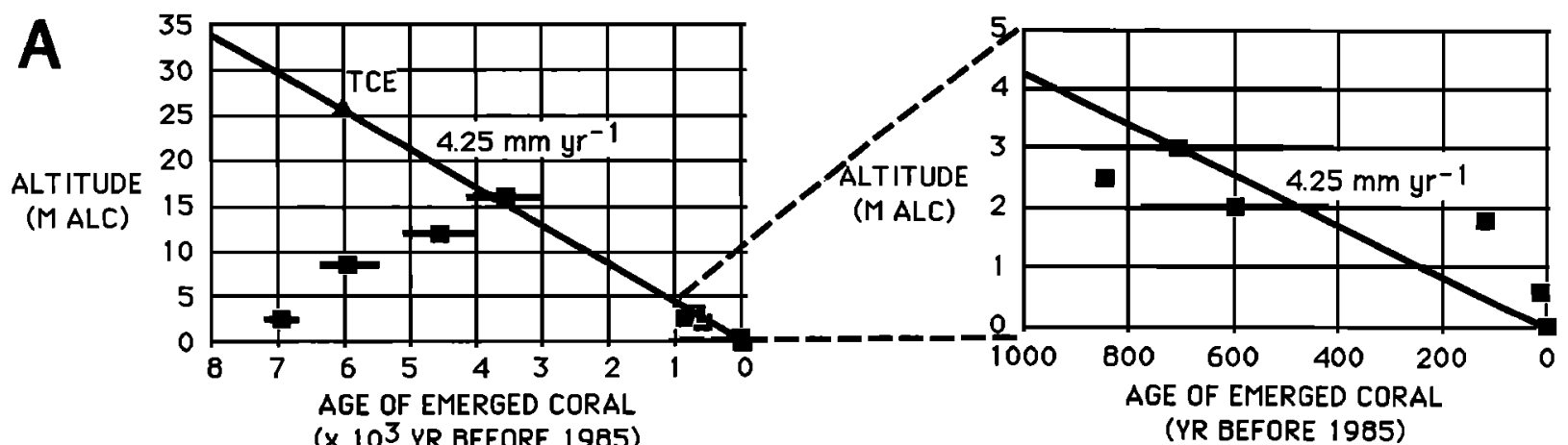

Fig. $3 a$

SOUTHWEST SANTO: AGE VS ALTITUDE

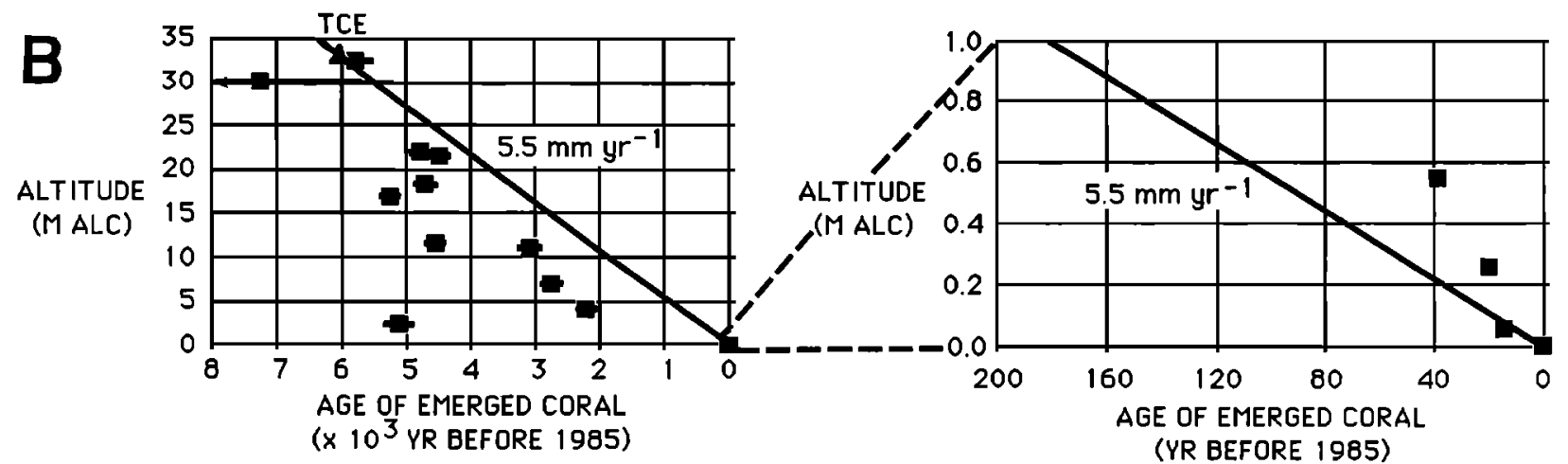

Fig. $3 b$

Fig. 3. Plots of age versus altitude for samples and uppermost Holocene terrace surfaces for four areas. Each area represents one of the four arc segments of central Vanuatu: (a) North Santo (NS). (b) South Santo (SS). (c) North Malekula (NM). (d) South Malekula (SM). Triangles represent the highest extent of Holocene coral limestone found at each locality. Squares represent ages and heights of samples with $2 \sigma$ error bars shown except where the area of symbols is larger than the $2 \sigma$ errors. Ages plotted include coral growth band, ${ }^{14} \mathrm{C}$ corrected to a 5730 year half life, and ${ }^{230}$ Th ages by both alpha spectrometer and by the mass spectrometric method [Edwards et al., 1988]. All ages are plotted in years before 1985 A.D. The age from the most precise method was plotted for any samples that were dated by more than one method. The hierarchy of precision from most to least precise is (1) coral growth bands, (2) ${ }^{230} \mathrm{Th}$ by mass spectrometry, (3) ${ }^{14} \mathrm{C}$, and (4) ${ }^{230} \mathrm{Th}$ by alpha spectrometry. Age data are from Taylor et al. [1980, 1981, 1987], Jouannic et al. [1980], Bloom and Yonekura [1985], Edwards et al. [1986, 1988], and several unpublished ${ }^{14} \mathrm{C}$ ages. Mean late Holocene uplift rates for each area are represeented by the sloping lines. To estimate mean uplift rates we assume that the uppermost surface of each Holocene reef terrace began to emerge about 6000 years ago and that sea level 6000 years ago was equal to present sea level. The lower right comer of each plot is expanded so that the youngest uplift events can be compared with mean Holocene uplift rates.

conclude that Holocene terraces are the result of paleoseismic uplifts because the Great Alaskan earthquake of 1964 produced the lowest terrace of the series. This approach contrasts with that presented for Kikai Island in the Ryukyu arc for several Holocene reef terraces occurring from sea level up to about $10 \mathrm{~m}$ altitude [Nakata et al., 1978; Ota et al., 1978]. Shimazaki and Nakata [1980] equated each terrace with a single coseismic uplift event even though there were no contemporary uplifts that supported this assertion.

\section{${ }^{230}$ Th Dating Methods}

The ${ }^{230} \mathrm{Th},{ }^{232} \mathrm{Th},{ }^{238} \mathrm{U}$, and ${ }^{234} \mathrm{U}$ abundances of corals were determined by thermal ionization mass spectrometry at the Lunatic Asylum at the California Institute of Technology
(Caltech). The ${ }^{230} \mathrm{Th}$ measurements have been described in detail by Edwards et al. [1987a] and Edwards [1988]. The ${ }^{234} \mathrm{U}$ measurements are described by Chen et al. [1986] and measurements of small amounts of uranium by Chen and Wasserburg [1981]. The thorium and uranium data for the Vanuatu corals (Table 1) are discussed in detail by Edwards et al. [1988].

\section{${ }^{14} \mathrm{C}$ Dating Methods}

Treatment of coral samples prior to ${ }^{14} \mathrm{C}$ dating included (1) slicing into 5 -mm-thick slabs and removing discolored or abnormal looking material, (2) soaking about 72 hours in $2 \%$ sodium hypochlorite solution, (3) cleaning in distilled water with an ultrasonic probe, and (4) examining by microscope for excessive aragonite cement. Powder $X$ ray 


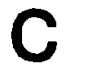

ALTITUDE (M ALC)

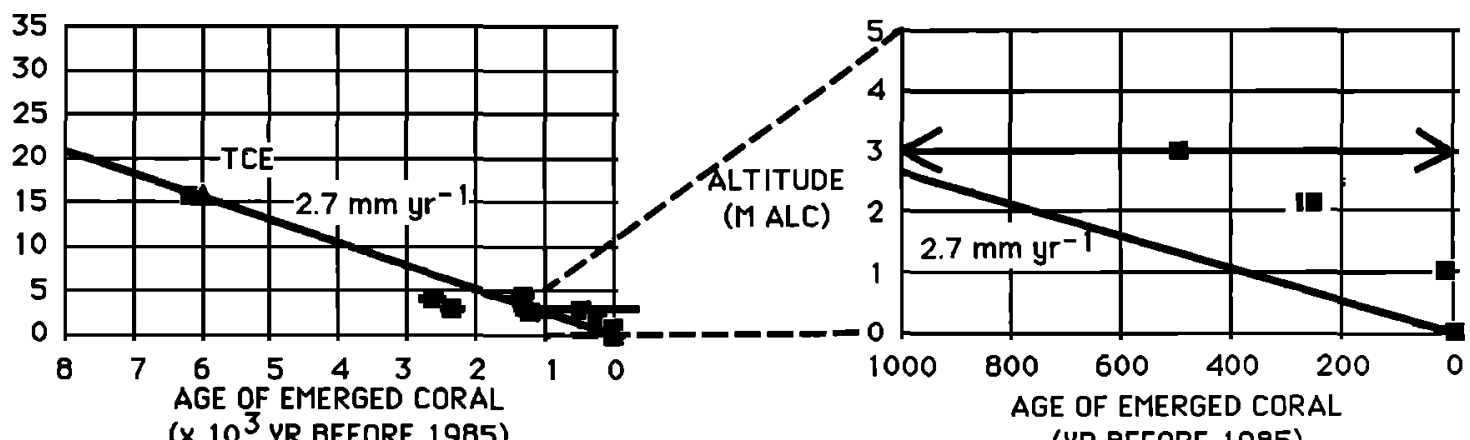

Fig. 3c

\section{SOUTH MALEKULA: AGE VS ALTITUDE}

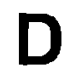

ALTITUDE

(M ALC)

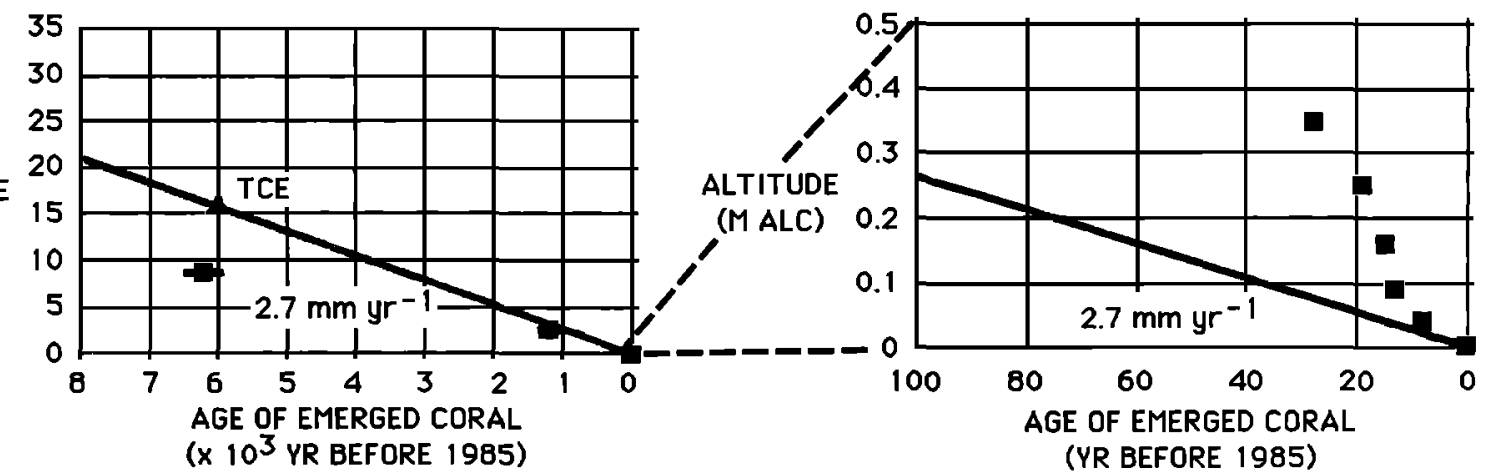

Fig. 3d

diffraction scans showed only peaks that could be attributed to aragonite. Calcite was not detectable in any samples. None had significant amounts of aragonite cement.

The ${ }^{14} \mathrm{C}$ ages in Figure 3 and Table 2 have been corrected for changes in the atmospheric ${ }^{14} \mathrm{C} /{ }^{12} \mathrm{C}$ ratio with time, using the curves of Stuiver [1982]. No corrections have been made for natural fractionation of carbon isotopes or for differences between the ${ }^{14} \mathrm{C} /{ }^{12} \mathrm{C}$ ratio in the growth reservoir and the atmosphere. Analytical errors for both ${ }^{14} \mathrm{C}$ and ${ }^{230} \mathrm{Th}$ ages are given as $\pm 2 \sigma$.

\section{Determination of Recurrence Intervals for Coseismic Uplift}

We present two types of recurrence intervals for each of the four arc segments. First, we have coral growth band and mass spectrometric ${ }^{230} \mathrm{Th}$ dates for corals killed by emergence events. These ages provide the actual time intervals between some younger coseismic uplifts, but they are too few to reveal average recurrence intervals. Second, we take the average increment of uplift per event $(U)$ and divide it by the mean Holocene uplift rate $(R)$ to obtain a mean Holocene recurrence interval $(T R)$ :

$$
T R=U / R
$$

For the youngest uplift events we can compare the measured time interval between them to the recurrence interval $T R$ as determined above. This provides some clues about possible variability of recurrence intervals for each segment.

Previous work, including more than 70 isotopic ages for Holocene samples, documents emergence of Holocene fringing reefs and uplift rates on Santo and Malekula during the past 6000-7000 years [Launay and Recy, $1972 ;$ Neef and Veeh, 1977; Taylor et al., 1980; Jouannic et al., 1980, 1982; Gilpin, 1982; Bloom, 1980; Bloom and Yonekura, 1985; Urmos, 1985]. By determining the maximum height of the Holocene terrace, we estimate the average rate $R$ at which emergence occurred. On each of the four arc segments, we determine an average Holocene uplift rate (Figure 1 and Table 3) for a specific locality where recent uplifts have occurred. These are (1) Olpoy (NS), (2) Tasmaloum (SS), (3) Unmak (NM), and (4) Benvat (SM) (Figure 1). The geomorphic continuity of Holocene terraces, their gradual changes in height, and the similarity of contemporary coseismic and Holocene uplift patterns indicate that we can generalize from a specific locality to the rest of each arc segment. An exception is SM where the vertical movement history suggests that the block does not move as a unit [Taylor et al., 1987].

To determine the mean uplift rate $R$, we must know the paleosea level at the time when each Holocene reef began to emerge in central Vanuatu. Data from the Vanuatu region suggest that Holocene sea level reached its present height, or a bit higher, by about 4000 [Maeda et al., 1986] to 6000 years B.P. [e.g., Baltzer, 1970; Thom and Chappell, 1975; Bloom, 1977; Ash, 1987]. This is generally consistent with hydroisostatic models of postglacial sea level rise [Clark et al., 1978].

We calculate Holocene uplift rates by dividing the altitude of the top of a Holocene terrace by the age of corals collected from the top of the terrace. The ${ }^{14} \mathrm{C}$ ages for 
samples from the uppermost Holocene reef surfaces range from $5635 \pm 320$ to $7685 \pm 460$ years B.P. (5730-year halflife $\pm 2 \sigma$ based on analytical uncertainties). However, such calculations may underestimate uplift rates because sea level about 6000 years ago may have been lower than present sea level, and the corals that were dated may have grown at some depth below the sea surface. Unfortunately, there is no generally accepted "eustatic" sea level history for this area that we can use.

In view of the above problems we choose two simplifying assumptions: (1) sea level during initial Holocene reef emergence was equal to present sea level, and (2) the uppermost Holocene reef is everywhere 6000 years old. Our mean Holocene uplift rates should be slightly less than the actual rates, and our average Holocene recurrence intervals should be somewhat longer than the true average. This is because the reefs should have begun to emerge when the mean uplift rate began to exceed the rate of submergence due to the rising Holocene sea level.

\section{MEAN HOLOCENE UPLIFT RATES AND TMMES AND AMOUNTS OF COSEISMIC EMERGENCE FOR SANTO AND MALEKULA}

\section{North Santo}

In 1979 and 1981 we measured $0.6 \mathrm{~m}$ of coral emergence at several places on northwest Santo. Counts of growth bands in samples from partially emerged corals indicated that the emergence occurred during a large earthquake on December 28, 1973 [Taylor et al., 1981, 1987] (Table 3). At a level $1.2 \mathrm{~m}$ higher, or about $1.8 \mathrm{~m} \mathrm{ALC} \mathrm{at} \mathrm{Olpoy,} \mathrm{we} \mathrm{also}$ discovered well-preserved dead corals (CWS-C and CWS-D) that appear to have emerged during a discrete event prior to 1973. The ${ }^{230}$ Th date for CWS-C is $1866 \pm 4$ A.D. and the average date of two samples of CWS-D is also 1866 A.D. (Tables 1 and 2). The interval between the two most recent major uplifts is then 107 years, and the average uplift was $0.9 \mathrm{~m}$. Because the Holocene terrace in this area is $25.5 \mathrm{~m}$ ALC, the mean Holocene uplift rate for this part of NS has been at least $4.25 \mathrm{~mm} \mathrm{yr}^{-1}$ (Figure 3).

\section{South Santo}

At Tasmaloum on SS (Figure 1) we have not yet isotopically dated any free-standing dead corals killed by a specific uplift event. However, previous coral growth band studies [Taylor et al., 1987] indicate $0.20 \mathrm{~m}$ of uplift here in 1965 and about $0.25 \mathrm{~m}$ of uplift in 1946 (Table 3). The smaller 1971 event, which caused $0.06 \mathrm{~m}$ of uplift here, is considered a delayed downdip rupture associated with the 1965 earthquake sequence so that the total 1965-related uplift is $0.26 \mathrm{~m}$. The Holocene terrace at Tasmaloum reaches to at least $33 \mathrm{~m} \mathrm{ALC}$ and the average uplift rate for the past 6000 years is at least $5.5 \mathrm{~mm} \mathrm{yr}^{-1}$ (Figure 3).

\section{North Malekula}

The August 11-13, 1965, earthquakes caused $1.05 \mathrm{~m}$ of uplift in the area near Unmak village (Figure 1), although maximum uplift as great as $1.2 \mathrm{~m}$ is found at the base of a Holocene reef reaching to $20 \mathrm{~m} \mathrm{ALC}$ at a point farther east [Taylor et al. 1980, Figure 7; Taylor et al., 1987, Figure 20]. Living corals do not record a large event prior to 1965. However, the emerged reef flat at Unmak has free-standing Goniastrea retiformis coral heads up to at least $1.23 \mathrm{~m}$ higher than the corals killed by uplift in 1965 (Figure 2). A thorough search revealed no intermediate level of emerged corals between these and the 1965 level. One of the emerged coral heads gave a ${ }^{230} \mathrm{Th}$ date of $1718 \pm 5 \mathrm{~A}$. D. and the other gave $1729 \pm 3$ A.D. (Tables 1 and 2). We assume that the younger date more closely approximates the time of emergence and that erosion removed the youngest part of the coral (M-AG-1) that recordes the older ${ }^{230} \mathrm{Th}$ date. Therefore the interval between the 1965 uplift and the previous uplift is 236 years (Table 3). The average uplift rate for the $16 \mathrm{~m}$ ALC Holocene reef near Unmak (Figure 1) is $2.7 \mathrm{~mm} \mathrm{yr}^{-1}$ (Figure 3).

\section{South Malekula}

In southernmost Malekula near the village of Benvat (formerly Malfakal), SM uplifted about $0.09 \mathrm{~m}$ near the time of the 1965 earthquake sequence. However, it also emerged slightly around 1957 and $0.12-0.16 \mathrm{~m}$ between 1965 and 1983 in the absence of any large earthquakes. It may have continued to emerge since our last visit in 1983. The total emergence of this area has been about $0.35 \mathrm{~m}$ over the past 25 years or so [Taylor et al., 1987]. This uplift may have been continual or episodic, but we consider all of it to be a single composite event. A Holocene reef at Benvat has emerged at least $16 \mathrm{~m}$ and indicates a mean uplift rate of at least $2.7 \mathrm{~mm} \mathrm{yr}^{-1}$ for the immediate area.

\section{ESTTMATES OF MEAN HOLOCENE RECURRENCE INTERVALS}

\section{North Santo}

The 1973 uplift was $0.6 \mathrm{~m}$ and the coral that died near 1866 indicates an additional $1.2 \mathrm{~m}$ of uplift which we assume occurred during a single event. The mean uplift per event is thus $0.9 \mathrm{~m}$ and the mean uplift rate is $4.25 \mathrm{~mm} \mathrm{yr}^{-1}$. This suggests a mean recurrence interval of 212 years compared with the dated interval of 107 years.

\section{South Santo}

If the mean uplift of $0.28 \mathrm{~m}$ for the two most recent events in 1946 and $1965-1971$ is typical, then the $5.5 \mathrm{~mm} \mathrm{yr}^{-1}$ uplift rate requires a recurrence interval of 51 years (Table $3)$. There is a rather large discrepancy between the 19-year interval (1946 to 1965-1971) and the 51-year interval. A longer record would be useful in explaining this discrepancy.

\section{North Malekula}

The 1965 uplift of about $1.05 \mathrm{~m}$ at Unmak and the 1729 corals at $1.23 \mathrm{~m}$ higher (Figure 2) indicate average uplifts of $1.14 \mathrm{~m}$ per event. A recurrence interval of 422 years is required to maintain the $2.7 \mathrm{~mm} \mathrm{yr}^{-1}$ uplift rate (Table 3). The mean recurrence interval of $\mathbf{4 2 2}$ years is considerably greater than the 236 years between the 1729 and 1965 uplifts. Additional undated emerged coral heads at about 3.5 m ALC ( about $1 \mathrm{~m}$ above the 1729 level) may represent a pre-1729 event.

\section{South Malekula}

The area for which we have uplift data apparently does not represent the rest of the SM arc segment. SM is a complex arc segment that behaves less coherently than the other three arc segments. We suspect that uplift of SM ceased or slowed during mid to late Quatemary time [Taylor et al., 1987] after 
a period of uplift that raised coral limestone to altitudes over $800 \mathrm{~m} \mathrm{ALC}$ in the island interior [Mitchell, 1966]. The emerged Holocene reef indicating a mean uplift rate of at least $2.7 \mathrm{~mm} \mathrm{yr}^{-1}$ and the recently emerged corals are located in a small domelike zone of renewed rapid uplift on southernmost Malekula. The significance of the uplift from 1957 to 1983, and its relationship to large interplate earthquakes is not clear, but the coral stratigraphy suggests that the uplift is distributed over a number of years rather than concentrated in one large coseismic event. With an uplift rate of $2.7 \mathrm{~mm} \mathrm{yr}^{-1}$ and uplift of $35 \mathrm{~cm}$ (so far), one infers a recurrence interval of about 130 years. If the present episode of uplift continues to raise southernmost SM, then the estimated recurrence interval for this pulse of uplift would be larger, unless subsidence plays a role in vertical deformation of this area.

If coupling between SM and the downgoing plate is weaker than for other blocks, the 1965 rupture may have propagated from NM beneath SM even though there were only a few associated aftershocks [Taylor et al., 1980]. Weaker coupling is possible because SM is not being underthrust by the DR which may be responsible for the strong coupling beneath NM and SS.

A local seismograph network operating since 1979 in Vanuatu recorded numerous small magnitude earthquakes beneath SM [Chatelain et al., 1986]. The location of this zone of concentrated seismicity is almost identical to the location of the zone of rapid Holocene and contemporary uplift identified independently by Taylor et al. [1987]. This suggests that continuous slip occurs beneath SM, that the slip is not completely aseismic, and that the interaction between the upper and lower plates is stronger here than in adjacent areas of SM where truly aseismic slip may occur. If uplift of SM from 1957 through 1983 represents interplate slip, SM appears to slip when loaded by rupture of an adjacent arc segment. Uplift at the rate observed for the past 35 years is not likely to continue indefinitely because the rate of uplift during this pulse is about 5 times the average Holocene uplift rate. The occurrence of post-1965 uplift with the concentrated zone of seismicity suggests that most of the SM segment is not coupled strongly enough to accumulate elastic strain leading to large thrusting earthquakes. A large shallow earthquake occurred near SM in 1927 [Gutenberg and Richter, 1954; McCann, 1980], but it may not have ruptured SM.

\section{ESTIMATES OF SEISMIC AND ASEISMIC SLIP}

In this section we estimate the amount of plate convergence accommodated by seismic slip (Table 4), as measured from the seismic moments of the largest earthquakes occurring in central Vanuatu since 1920 . We choose 1920 because this is approximately when the catalog of Gutenberg and Richter [1954] begins to be complete for earthquakes with surface wave magnitudes of 7.0 or greater. To estimate the total slip, we use an INDI-PCFC plate convergence rate of $10 \mathrm{~cm} \mathrm{yr}^{-1}$ which represents the average rate over millions of years [Minster and Jordan 1978; Gordon et al., 1988]. Since back arc basin spreading on the Fiji plateau may require the addition of as much as $6 \mathrm{~cm} \mathrm{yr}^{-1}$ [Chase, 1971] to $9.6 \mathrm{~cm} \mathrm{yr}^{-1}$ [Falvey, 1975; Malahoff et al., 1982] to the convergence rate at the Vanuatu trench, our estimates of the fraction of seismic slip are probably too large. Nevertheless, we shall find that maximum seismic slip is significantly less than the $50 \%$ suggested for Vanuatu by Lay and Kanamori [1981] and Lay et al. [1982].

The relation between seismic moment $M_{\mathrm{o}}$ and mean fault slip, $s$, on a fault of surface area $A$ is

$$
M_{\mathrm{o}}=\mu A s
$$

where $\mu$ is the rigidity of rocks in the fault region. When the fault slip occurs suddenly, it produces earthquake body and surface waves, and the associated moment can be measured from seismograms [Aki and Richards, 1980]. Even when the fault area $A q$ for a particular earthquake is unknown, equation (2) permits one to estimate the average contribution of the earthquake to slip $s$ along a larger segment of the plate boundary having area $A s$. In this study, we estimate $A s$ from the approximate length of segments as shown in Figure 1 and the approximate width of the aftershock zones of the 1965 and 1973 earthquakes as shown by Isacks et al. [1981]. For the SM segment, we arbitrarily choose the width as 70 $\mathrm{km}$. For the rigidity, we follow Ebel [1980] and use a value of $5.6 \times 10^{11} \mathrm{~g} \mathrm{~cm} \mathrm{~s}^{-2}$, corresponding to a shear velocity of $4.3 \mathrm{~km} \mathrm{~s}^{-1}$ and a density of $3.2 \mathrm{~g} \mathrm{~cm}^{-3}$.

Although earthquakes of all sizes may contribute to the slip along a plate boundary, over time the largest earthquakes in any area produce nearly all the moment or slip. This is because over extended periods the relationship between earthquake frequency $N$ and moment $M_{\mathrm{o}}$ is found empirically to satisfy a Gutenberg-Richter relation like

$$
\log _{10} N=a^{\prime}-b^{\prime} \log _{10} M_{\mathrm{o}}
$$

where $b^{\prime}$ is always less than 1.0. Under this condition a simple sum or integration shows that the contribution of the small events to the total moment is negligible.

Thus one of the most serious uncertainties with using earthquakes to measure average fault slip is that the largest earthquake possible along any particular fault segment may not have occurred during historic times. However, the paleoseismic data (Tables 1, 2, and 3) and general similarity between the average Holocene recurrence intervals and recent recurrence intervals suggest that there was not a greater frequency of large interplate thrust-type earthquakes along most segments and that the historic record of earthquakes is similar to seismicity over the past few hundred years.

A second difficulty is that different methods for estimating seismic moment produce results which commonly differ by factors of 3 or more. Some of this is expected because the slip radiated by surface waves of period 20-200 s would include, and thus be greater than, the slip radiated by body waves of period 1-5 s. What we call aseismic slip is that which occurs over periods significantly longer than $200 \mathrm{~s}$. For this study (Table 4), we evaluate a range of possible seismic moments using the values reported in the literature or inferred from the surface wave magnitude/moment relation of Hanks and Kanamori [1979]. Although there is considerable uncertainty in the exact values for the parameters in the moment/magnitude equation [e.g., see Hanks and Boore, 1984], the equation we use is the one most commonly applied for large earthquakes. As there has been no special analysis of the moment/magnitude relationship for Vanuatu earthquakes, we think that it is the appropriate equation for the present analysis.

In NS, only two significant earthquakes have occurred since 1920. The first occurred on December 28, 1973, an event with $M_{S}=7.2$ and a reported $M_{\mathrm{o}}=29 \times 10^{25}$ dyne cm 
[Chinn and Isacks, 1983]. A larger event having $M_{S}=7.5$ occurred the next day. For both events the moment estimated from the surface wave magnitude using the relationship of Hanks and Kanamori [1979] is considerably larger than the Chinn and Isacks [1983] estimate. We assume a segment length of $100 \mathrm{~km}$ and an aftershock width of $115 \mathrm{~km}$, as indicated by Figure 10 of Isacks et al. [1981]. We assume a fault dip of $30^{\circ}$. Under these assumptions the total seismic slip is less than half a meter, which represents less than $10 \%$ of the plate convergence predicted to occur since 1920 .

We here consider the SS and NM segments jointly, as the August 11, $1965\left(M_{S}=7.5\right)$, event had two large foreshocks and two large aftershocks which apparently ruptured both segments, and possibly the SM segment as well. We include the October 27, 1971, event $\left(M_{S}=7.1\right)$ under $S S$ as a delayed part of this sequence [Taylor et al., 1987]. All are classed as interplate thrust-type events [Chinn and Isacks, 1983]. For this sequence the surface wave moments of Ebel [1980] are significantly larger than either the body wave moments or those estimated from surface wave magnitudes. The total seismic moment for these events may have been as large as $700 \times 10^{25}$ dyne $\mathrm{cm}$. For a segment length of $100 \mathrm{~km}$ and a fault width of $80 \mathrm{~km}$ [Isacks et al., 1981] the seismic slip for this sequence was about $1.5 \mathrm{~m}$. Events with $M_{S}=7.0$ and 7.3 occurring in 1946 have contributed an additional $0.30 \mathrm{~m}$ or so of slip, but still this represents less than one third of the plate convergence expected since 1920 . We note that Taylor et al. [1980] could model the observed uplift pattern from emerged corals associated with this event using the methods of Savage and Hastie [1966] and a slip of $5.3 \mathrm{~m}$ along a fault dipping $30^{\circ}$. Later, using the model of Savage and $G u$ [1985] and a fault dip of 50', Taylor et al. [1987] required only $2.0 \mathrm{~m}$ of slip.

In SM, the only known large event in the vicinity had a $M_{S}$ of 7.1 and occurred in 1927. Using this magnitude to estimate moment gives a seismic slip of $0.24 \mathrm{~m}$, which accommodates less than $5 \%$ of the plate motion since 1920 .

Furthermore, the emerged corals indicating uplift in about 1866 and 1729 suggest earthquake sequences similar to those associated with the earthquakes occurring in 1973 and 1965 on the NS and NM segments, respectively. The 1866 uplift on NS was about $1.2 \mathrm{~m}$ or about twice that observed for the 1973 event. Between 1866 and $197310.7 \mathrm{~m}$ of plate convergence occurred, so that the maximum of $0.47 \mathrm{~m}$ of seismic slip calculated for the 1973 sequence accounts for about $4 \%$ of this. Similarly, for the SS and NM segments combined, the estimated $1.8 \mathrm{~m}$ of slip estimated from the moment of the 1965 sequence is about $8 \%$ of the $23.6 \mathrm{~m}$ of plate convergence between the 1729 and 1965 uplifts. Except in SM, there is no evidence that significant uplift occurred in years not having large shallow earthquakes.

While there are uncertainties in these estimates of the fraction of seismic slip, the authors of the present study believe that it is possible, but not very likely, that they are large enough to nullify our conclusion that the seismic slip rate is considerably smaller than the plate convergence rates reported by Minster and Jordan [1978] and Gordon et al. [1988]. For our purposes, their values for the plate convergence are conservatively low as they ignore possible contributions due to back arc spreading. Our estimates of fault segment dimensions (Table 4) are realistic, as they assume that the seismic energy radiates from the surface to the depth of the deepest aftershocks along the entire segment length. Wherever possible in Table 4, we include a range of slip estimates determined from the whole range of published moments. Our conclusion that there is a discrepancy between the seismic slip rate and the plate convergence rate holds even if our largest estimates of the rate underestimate the seismic slip by a factor of 2 .

\section{DISCUSSION}

\section{Recurrence Intervals}

In this study, we have dated large uplift events for several segments of the central Vanuatu arc. Establishing recurrence intervals is difficult even in areas having a long historical record but is especially difficult in regions such as Vanuatu where the historical record extends back less than a century. It appears that we can now reconstruct the details of contemporary vertical movements in tropical arcs and extend the record of vertical tectonism at least several centuries into the past.

Previous estimates of 25- to 40-year repeat times for Vanuatu interplate seismic ruptures [Lay and Kanamori, 1981] are too short for most of central Vanuatu. The seismic potential of central Vanuatu [e.g. McCann et al., 1979; McCann, 1980] can be revised based on the more detailed understanding of the relation of historical and prehistoric earthquakes to the uplifting segments of the central Vanuatu arc. Previous studies probably assumed incorrectly that all of the large shallow events reported in central Vanuatu by Gutenberg and Richter [1954] ruptured arc segments. For example, two events in $1946\left(M_{S}=7.3\right.$ and 7.0) were reported for central Vanuatu. Uplift of SS in 1946 [Taylor et $a l ., 1987]$ indicates that SS ruptured and that McCann's [1980] relocation of the $M_{S}=7.3$ event (January 5,1946 ) under SS is correct. However, the absence of 1946 uplift of NM suggests that the Gutenberg and Richter [1954] location under NM for the $M_{S}=7.0$ (January 20, 1946) event may be incorrect or that it was not a thrust-type event. Perhaps this smaller event was an aftershock of the larger event under SS.

Mean Holocene recurrence intervals (51-422 years) for central Vanuatu and dated interseismic uplift intervals of 19236 years are comparable to those for the Nankai trough $(\sim 170 \pm 70$ years) [Yonekura, 1975] or southem Chile (100162 years) [Kelleher, 1972]. However, those areas tend to have much larger ruptures associated with earthquakes of $M_{S} \geq$ 8.0 whereas the largest known central Vanuatu events have $\mathrm{M}_{\mathrm{S}}=7.5$.

With a mean recurrence interval of 51 years, and 19 years between the 1946 and 1965 uplifts, SS has the highest frequency of large shallow earthquakes causing uplift. Of the four arc segments, SS is the most likely site for the next large shallow earthquake causing uplift. NM and the western part of NS are not due for additional coseismic uplift for many years as forecast by either mean Holocene recurrence intervals or from dated intervals between the two most recent uplifts. However, as noted by Taylor et al. [1987], the eastern part of NS appears to have uplifted less in 1973 in proportion to its total Holocene emergence than did western NS on which we base our estimates. It seems possible that creep or rupture downdip of the 1973 rupture surface may cause uplift of the eastem peninsula of NS and eliminate the uplift deficit of eastem NS. According to our estimates, NM is not due for major coseismic uplift for more than 200 years. However, our data are too few to reveal the variability in recurrence times between major coseismic uplifts for any of the four arc segments.

The concentration of seismicity in the area of rapid uplift on SM [Chatelain et al., 1986; Taylor et al., 1987] may be 
due to loading caused by the 1965 rupture of the adjacent NM arc segment. The ongoing uplift may be temporary as the uplift rate from 1957 to 1983 is far more rapid than the mean Holocene rate. We suspect that if the seismicity rate under this part of SM diminishes, the uplift rate will decrease as well. The seismicity and uplift of SM may be similar to that elsewhere in the arc where the DR is not underthrusting. For example, there are nests of seismicity between 1978 and the present west and northwest of Efate [Chatelain et al., 1986]. Vertical deformation also may occur offshore near Efate, but there is no nearby land on which to document it. However, J.L. Chatelain and B.L. Isacks (personal communication, 1987) recorded tilt events on Efate in association with the clusters of seismicity. Perhaps these clusters occur as subduction of rugged topography creates temporary asperities and uplift, whereas subduction of the DR causes long-term asperities and uplift patterns which change much more slowly with time.

Our results clearly demonstrate that there is considerable variation from segment to segment for the time intervals between the most recent coseismic uplifts, amounts of coseismic uplift, and mean recurrence intervals based on Holocene uplift rates. This implies that adjacent arc segments have different characteristics with respect to the accumulation and release of elastic strain. A possible complication is suggested by the 1965 simultaneous rupture of SS, NM, and, apparently, part of SM. The NS segment ruptured only 8 years later in 1973, possibly due to increased loading from the SS rupture. It appears that either simultaneous rupture of adjacent blocks may occur as in 1965 , or segments may rupture individually as SS in 1946 and NS in 1973.

Total Holocene uplift in Table 3 and thus the estimated mean uplift rates are probably too low. If this is the case, then mean recurrence intervals are probably shorter than we have estimated. This would help explain why contemporary uplifts are larger than predicted by our known interseismic intervals and minimum estimates for uplift rates. Furthermore, faster uplift rates would make measured and estimated recurrence intervals more consistent.

\section{Amount and Timing of Aseismic Slip}

The data that we have obtained place constraints on the amount and timing of seismic and aseismic slip in central Vanuatu. If our analysis of seismic moment is correct and if the plates presently converge at approximately the rate reported by Minster and Jordan [1978], our principal conclusion is that most of the slip is aseismic. Indeed, our calculations indicate that the earthquake moments represent less than one-third to one-tenth of the plate convergence since 1920. Furthermore, the coral uplift record suggests that prior to 1920 , no significant aseismic slip occurred in SS-NM since about 1729, unless aseismic slip does not cause uplift. This would indicate that less than $10 \%$ of the slip is radiated as seismic energy throughout central Vanuatu. All our estimates of seismic slip are less than the roughly $50 \%$ seismic slip rate estimated by Lay and Kanamori [1981]. However, they estimated repeat times at only 25-40 years, possibly because they used a rather low convergence rate of

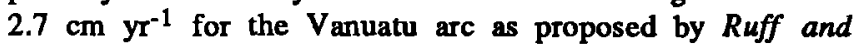
Kanamori [1980].

If much of the fault slip associated with plate convergence in central Vanuatu does not contribute to seismic moments, when exactly does slip occur? If both seismic and aseismic slip produce uplift, then our data strongly suggest that, except in SM, the slip occurs in the same year as do major earthquakes. Except on SM, we find no evidence that coral uplift occurs continually at regular intervals from year to year or that it occurs at variable annual rates which change over the course of the earthquake cycle. Rather, as measured by the annual growth bands of corals, nearly all the uplift appears to be coseismic. We speculate that most of this aseismic slip occurs as rapid fault creep in the hours or days before and after major earthquakes. This could explain the temporary change in sea level of at least $2.5 \mathrm{~m}$ reported at one location on SS on the morning of the main shock of the 1965 earthquake sequence [Taylor et al., 1987].

\section{Degree of Interplate Coupling}

Recently, a number of investigators have explained the tectonic characteristics of different island arc systems in terms of the degree of coupling between the subducting and overriding plates [e.g., Kanamori, 1977; Uyeda and Kanamori, 1979; Lay and Kanamori, 1981; Jarrard, 1986]. In these schemes, they classify Vanuatu along with Middle America as having coupling of intermediate strength on the basis of the sizes of the largest earthquakes and their tendency to cluster [Kelleher et al., 1974; Lay and Kanamori, 1981]. However, the smaller proportion of seismic slip and relatively longer mean recurrence intervals indicated by the present study suggest that the coupling may be somewhat less than in Middle America. This conclusion is consistent with the back arc spreading on the Fiji plateau [Chase, 1971] and, perhaps, in the Coriolis trough and related features [Dubois et al., 1975]. The back arc opening of Middle America, which may occur in the Nicaraguan depression, is much less decisive.

There is some evidence that the coupling in much of the Vanuatu arc is even less than that in central Vanuatu, where subduction of the DR occurs. Supporting evidence for this statement includes (1) the absence of segments of the extensional Coriolis trough system behind the interval of the arc treated in this paper, (2) four shallow earthquakes in the central Vanuatu back arc whose focal mechanisms indicate compression [Marthelot et al., 1985], and (3) the relatively strong coupling suggested by the occurrence of several large shallow earthquakes where the DR intersects the arc. However, events having $M_{S} \geq 8$ have occurred near the Torres Islands at $13^{\circ} \mathrm{S}$ and suggest that this particular area may be even more strongly coupled than central Vanuatu.

Generally, in Vanuatu we are better able to characterize the nature of seismicity, recurrence intervals, and amount of aseismic subduction within individual arc segments of length $50-100 \mathrm{~km}$, rather than along the entire arc. In this respect the convergent plate boundary in Vanuatu appears similar to the strike-slip boundary in Califomia. In California, earthquakes take up much of the fault motion along some segments of the boundary. Along others the motion occurs primarily as aseismic fault creep, and elsewhere the fault is locked [Scholz et al., 1969; Burford and Harsh, 1980; Louie et al., 1985].

\section{CONCLUSIONS}

We have applied a combination of techniques to document the uplift history on Vanuatu coasts. The five elements of our approach include (1) coral growth band dating of the times of partial emergence of still-living corals; (2) recognition of emerged fossil corals killed by discrete 
emergence events, (3) high-precision $230 \mathrm{Th} / 234 \mathrm{U}$ dating that avoids many problems inherent in dating of coral samples, (4) measurement of the height and age of the Holocene terraces for determination of mean uplift rates, and (5) determination of seismic slip as estimated from the moments of large, historical earthquakes. The first four of these methods can be applied to improve the history of uplift in Vanuatu and in other tropical coasts even where little or no historical record of earthquakes exists.

Our results for central Vanuatu suggest that recurrence intervals are quite different for each of the four semiindependent arc segments (Figure 1). Mean Holocene recurrence intervals for each arc segment are (1) NS $=212$ years; (2) SS = 51 years; (3) $\mathrm{NM}=422$ years; and (4) $\mathrm{SM}$ $=\geq 130$ years. The dated intervals between the most recent uplifts are (1) NS = 107 years; (2) SS = 19 years; (3) $\mathrm{NM}=$ 236 years, and (4) $S M=$ unknown.

If plate convergence in the latest Holocene has taken place at the long-term mean rate reported by Minster and Jordan [1978], then our calculations suggest that most of the plate convergence at central Vanuatu is accommodated by aseismic slip. Since 1920 SS probably has had the highest proportion of seismic slip, which seems consistent with its relatively short seismic recurrence times and rapid uplift rate of at least $5.5 \mathrm{~mm} \mathrm{yr}^{-1}$. SS clearly may have greater potential for a large shallow earthquake accompanied by uplift in the future in view of its greater seismic slip, short recurrence interval, and 19-year period between the two most recent coseismic uplifts. Except on SM, we find little or no evidence that significant amounts of slip occur except in years when large earthquakes occur. This suggests that most of the aseismic slip must occur at about the same time as the earthquakes. SM appears to have a more complex style of strain release that may be characterized by continuous or episodic uplift occurring with small magnitude earthquakes rather than infrequent large ruptures. If the strain release is episodic then in SM a comparison of the contemporary uplift and the Holocene uplift rate implies a recurrence interval of greater than 130 years for pulses of uplift (Table 3).

Acknowledgments. We particularly thank R. Campillo, C. Reichenfeld, C. S. Cheney, J.-L. Saos, A. Macfarlane, D. Sogari, the crews of the vessels Vauban and Lopevi, P. Vuti, J.-L. Laurent, Michel Caffin, C. Jouannic, P. Maillet, L. Gilpin, M. Strecker, Alfred Stevens, Stan Combs, Chief Kalman of Brenwe, many other people from villages on Santo, Malekula, and neighboring islands, and the govemment of Vanuatu for assistance rendered during field work leading to this paper. We thank A. L. Bloom and B. Isacks for helping to inspire this project and for continuing encouragement. The $230 \mathrm{Th}$ analyses were performed at the Lunatic Asylum at Caltech with advice and support from J.H. Chen and D.A. Papanastassiou. This document was written while R.L.E. was supported by the Department of Geology and Geophysics at the University of Minnesota. This work was supported by NSF grants EAR 7919912, EAR-8507983, EAR-8618406, EAR-8843928, and EAR-8904987 to The University of Texas at Austin. EAR-7815188 to Comell University, EAR-8904705 to the University of Minnesota, the Government of Vanuatu, and ORSTOM. The University of Texas at Austin Institute for Geophysics contribution 787. California Institute of Technology, Division of Geological and Planetary Sciences contribution 4690 (643); University of Minnesota, Departinent of Geology and Geophysics contribution 1122(7).

\section{REFERENCES}

Aki, K., and P. G. Richards, Quantitative Seismology, Theory and Methods, 932 pp., W. H. Freeman, New York, 1980.

Ash, J., Holocene sea levels in northem Viti Levu, Fiji, N. Z.J. Geol., 30, 431-435, 1987.
Baltzer, M. F., Datation absolue de la transgression holocène sur la côte ouest de Nouvelle-Calédonie sur des échantillons de tourbes à palétuviers: Interpretation néotectonique, C. R. Acad. Sci., 271, 2251-2254, 1970.

Bevis, M., and B. L. Isacks, Leveling arrays as multicomponent tiltmeters: Slow deformation in the New Hebrides island arc, $J$. Geophys. Res., 86, 7808-7824, 1981.

Bloom, A. L., Atlas of sea-level curves, UNESCO IGCP Project 61, Sea-Level Project, Comell Univ., Ithaca, N. Y., 1977.

Bloom, A. L., Late Quaternary sea level change on south Pacific coasts: A study in tectonic diversity, in Earth Rheology, Isostasy, and Eustasy, edited by N. A. Momer, Pp. 505-516, Wiley-Interscience, New York, 1980.

Bloom, A. L., and N. Yonekura, Coastal terraces generated by sealevel change and tectonic uplift, in Models in Geomorphology, edited by $M$. J. Woldenberg, pp. 139-153, Allen and Unwin, Winchester, Mass., 1985.

Burford, R. O., and P. W. Harsh, Slip on the San Andreas fault in central California from alinement array surveys, Bull. Seismol. Soc. Am., 70, 1233-1261, 1980.

Chase, C. G., Tectonic history of the Fiji Plateau, Geol., Soc. Am. Bull., 82, 3087-3110, 1971.

Chatelain, J.-L., B. L. Isacks, R. K. Cardwell, R. Prevot, and M. Bevis, Patterns of seismicity associated with asperities in the central New Hebrides island arc, J. Geophys. Res., 91, 12,497$12,519,1986$.

Chen, J.H. and G.J. Wasserburg, Isotopic determination of uranium in picomole and subpicomole quantities, Anal. Chem., 53, 2060-

2067. 1981.
Chen, J.H., R.L. Edwards, and G.L. Wasserburg, ${ }^{238} \mathrm{U},{ }^{234} \mathrm{U}$, and ${ }^{232} \mathrm{Th}$ in seawater, Earth Planet. Sci. Lett., 80, 241-251, 1986.

Chinn, D., and B. L. Isacks, Accurate source depths and focal mechanisms of shallow earthquakes in western South America and in the New Hebrides island arc, Tectonics, 2, 529-563, 1983.

Clark, J. A., W. E. Farrell, and W. R. Peltier, Global changes in postglacial sea level: A numerical calculation, Quat. Res. ,9, 265278, 1978.

Collot, J. Y., J. Daniel, and R. V. Bume, Recent tectonics associated with the subduction/ collision of the d'Entrecasteaux zone in the central New Hebrides, Tectonophysics, 112, 325$356,1985$.

DeBievre, P., K. J. Lauer, Y. Le Duigon, H. Moret, G. Muschenbom, J. Spaeper, A. Spernal, R. Vaninbroukx, and V. Verdingh, The half-life of ${ }^{234} \mathrm{U}$, in Proceedings of International Conference on Chemistry of Nuclear Data, Measurements and Applications, Canterbury, edited by M.L. Hurrell, Pp. 221-225, Institute of Civil Engineers, London, 1971.

Dubois, J., F. Dugas, A. Lapouille, R. Louat, and C. Ravenne, Fossés d'effondrement en arrière de l'arc des Nouvelles-Hébrides: Mécanismes proposés, Rev. Geogr. Phys. Géol. Dyn., 17. 73-94, 1975.

Ebel, J. E., Source processes of the 1965 New Hebrides Islands earthquakes inferred from teleseismic wave forms, Geophys. $J$. $R$. Astron, Soc., 63, 381-403, 1980.

Edwards, R. L., High precision ${ }^{230} \mathrm{Th}$ ages of corals and the timing of sea level fluctuations in the late Quatemary, Ph.D. dissertation, 347 pp., Calif. Inst. of Technol., Pasadena, 1988.

Edwards, R. L., J. H. Chen, and G. J. Wasserburg, ${ }^{238} \mathrm{U}-{ }^{234} \mathrm{U}-{ }^{230} \mathrm{Th}-$ ${ }^{232}$ Th systematics and the precise measurement of time over the past 500,000 years, Earth Planet. Sci. Lett., 81, 175-192, $1987 a$.

Edwards, R. L., J. H. Chen, T.-L. Ku, and G. J. Wasserburg, Precise timing of the last interglacial period from mass spectrometric determination of thorium-230 in corals, Science, 236, 15471553, $1987 b$.

Edwards, R. L., F. W. Taylor, J. H. Chen, and G. J. Wasserburg, High precision thorium-230 dating of corals using thermal ionization mass spectrometry: Applications to paleoseismology, Proceedings of Conference XXXIX, Directions in
Paleoseismology, edited by A. J. Crone and E. M. Omdahl, U.S. Geol. Surv. Open File Rep. 87-673, 30-38, 1987 c.

Edwards, R. L., F. W. Taylor, and G. J. Wasserburg, Dating Earthquakes with high precision $230_{\mathrm{Th}}$ ages of very young corals, Earth Planet. Sci. Lett., 90, 371-381, 1988.

Falvey, D. A., Arc reversals and a tectonic model for the North Fiji Basin, Bull. Aust. Soc. Explor. Geophys., 6, 47-49, 1975.

Fitch, T. J., and C. H. Scholz, Mechanisms of underthrusting in southwest Japan: A model of convergent plate interactions, $J$. Geophys. Res., 76, 7260-7292, 1971. 
Gilpin, L. M., Tectonic geomorphology of Santo Island, Vanuatu (New Hebrides), M.S. thesis, 147 PP., Comell Univ., Ithaca, N. Y., 1982.

Gordon, R. G., G. Demets, D. F. Argus, and S. Stein, Current plate motions, Eos Trans. AGU, 69, 1416, 1988.

Gutenberg, B., and C. F. Richter, Seismicity of the Earth, 2nd ed., pp. 161.234, Princeton University Press, Princeton, N. J., 1954.

Hanks, T. C., and D. M. Boore, Moment-magnitude relations in theory and practice, J. Geophys. Res., 89, 6229-6235, 1984.

Hanks, T. C., and H. Kanamori, A moment magnitude scale, $J$. Geophys. Res., 84, 2348-2350, 1979.

Isacks, B. L., R. K. Cardwell, J.-L. Chatelain, M. Barazangi, J. M Marthelot, D. Chinn, and R. Louat, Seismicity and tectonics of the central New Hebrides Island Arc, in Earthquake Prediction: An International Review, Maurice Ewing Ser., vol. 4, edited by D. W. Simpson and P. G. Richards, pp. 93-116, AGU, Washington, D. C., 1981.

Jaffey, A. H., K. F. Flynn, L. W. Glendenin, W. C. Bentley, and A M. Essling, Precision measurements of half-lives and specific activities of ${ }^{235} \mathrm{U}$ and $238 \mathrm{U}$, Phys. Rev. C, 4, 1889-1906, 1971.

Jarrard, R. D., Relations among subduction parameters, Rev. Geophys., 24, 217-284, 1986.

Jouannic, C., F. W. Taylor, A. L. Bloom, and M. Bernat, Late Quaternary uplift history from emerged reef terraces on Santo and Malekula islands, central New Hebrides island arc, Tech. Bull. 3 , pp. 91-108, UN ESCAP, CCOP/SOPAC, Wellington, N.Z., 1980.

Jouannic, C., F. W. Taylor, and A. L. Bloom, Sur la surrection et la déformation d'un arc jeune: l'arc des Nouvelles-Hébrides, Trav. Doc. ORSTOM, 147, 223-246, 1982.

Kanamori, H., Seismic and aseismic slip along subduction zones and their tectonic implications, in Island Arcs, Deep Sea Trenches, and Back-Arc Basins, Maurice Ewing Ser., vol. 1, edited by $\mathbf{M}$. Talwani, C. G. Harrison, and D. E. Hayes, Pp. 163-174, AGU Washington, D. C., 1977.

Kelleher, J. A., Rupture zones of large South American earthquakes and some predictions, J. Geophys. Res., 77, 2087-2103, 1972.

Kelleher, J., J. Savino, H. Rowlett, and W. McCann, Why and where great thrust earthquakes occur along island arcs, J. Geophys. Res. 79, 4889-4899, 1974.

Kroenke, L. W., C. Jouannic, and P. Woodward, Bathymetry of the southwest Pacific, Geophysical Atlas of the Southwest Pacific, UNIGCP 110, chart 1, United Nations ESCAP, New York, 1983.

Launay, J., and J. Recy, Variations relatives du niveau de la mer et neotectonique en Nouvelle Caledonie au Pleistocene superior et a 1'Holocene, Rev. Geogr. Phys. Geol. Dyn., 14, 47-66, 1972.

Lay, T., and $H$. Kanamori, An asperity model of large earthquake sequences, in Earthquake Prediction: An International Review, Maurice Ewing Ser., vol. 4, edited by D. W. Simpson and P. G. Richards, pp. 579-592, AGU, Washington, D. C., 1981.

Lay, T., H. Kanamori, and L. Ruff, The asperity model and the nature of large subduction zone earthquakes, Earthquake Predict. Res., 1, 3-71, 1982.

Louie, J. N., C. R. Allen, D. C. Johnson, P. C. Haase, and S. N. Cohn, Fault slip in southern Califomia, Bull. Seismol. Soc. Am. $75,811-833,1985$.

Lounsbury, M., and R. W. Durham, The alpha half-life of ${ }^{234} U$, in Proceedings of International Conference on Chemistry of Nuclear Data, Measurement and Applications, Canterbury, edited by M. L. Hurrell, 215-219, Institute of Civil Engineers, London, 1971.

Maeda, Y., T. Miyata, P. Rodda, A. Sugimura, E. Matsumoto, and Y. Matsushima, Holocene sea-level changes in Viti Levu and Vanua Levu, Fiji, in Sea-Level Changes and Tectonics in the Middle Pacific, Report of the HIPAC Project in 1984 and 1985, edited by A. Sugimura, pp. 71-92, Kobe University, Kobe, Japan, 1986.

Malahoff, A., R. H. Feden, and H. S Fleming, Magnetic anomaly and tectonic fabric of marginal basins north of New Zealand, $J$. Geophys. Res., 87, 4109-4125, 1982.

Marthelot, J. M., J. L. Chatelain, B. L. Isacks, R. K. Cardwell, and $\mathrm{E}$. Coudert, Seismicity and attenuation in the central Vanuatu (New Hebrides) Islands: A new interpretation of the effect of subduction of the d'Entrecasteaux fracture zone, J. Geophys. Res. $90,8641-8650,1985$.

McCann, W. R., Large and moderate size earthquakes: Their relationship to the tectonics of subduction, Ph.D. dissertation, Columbia Univ., New York, 1980.

McCann, W. R., S. Nishenko, L. Sykes, and J. Krause, Seismic gaps and plate tectonics: Seismic potential for major plate boundaries, Pure Appl. Geophys., 117, 1082-1147, 1979.
Meadows, J. W Half-life of ${ }^{2}{ }^{\circ} 0 \mathrm{Th}$, Phys. Rev. C, 22, 750-754, 1980.

Minster, J. B., and T. H. Jordan, Present-day plate motions, $J$. Geophys. Res., 83, 531-5354, 1978.

Mitchell, A. H. G., The geology of south Malekula, Reg. Rep. 3, 42 pp., New Hebrides Geol. Surv., Vila, 1966.

Nakata, T., T. Takahashi, and M. Koba, Holocene emerged coral reefs and sea-level changes in the Ryukyu Islands (in Japanese), Geogr. Rev. Jpn., 51, 87-108, 1978.

Neef, G., and H. H. Veeh, Uranium-series ages and late Quaternary uplift in the New Hebrides, Nature, 269, 682-683, 1977.

Ota, Y., H. Machida, N. Hori, K. Konishi, and A. Omura, Holocene raised coral reefs of Kikai-Jima (Ryukyu Islands) - An approach to Holocene sea level study (in Japanese), Geogr. Rev. Jpn., 51, $109-130,1978$.

Pascal, G., B. L. Isacks, M. Barazangi, and J. Dubois, Precise relocations of earthquakes and seismotectonics of the New Hebrides island arc, J. Geophys. Res., 83, 4957-4973, 1978.

Plafker, G., Application of marine-terrace data to paleoseismic studies, Proceedings of Conference XXXIX, Directions in Paleoseismology, edited by A. J. Crone and E. M. Omdahl, U.S. Geol. Surv. Open File Rep., 87-673, 146-156, 1987.

Plafker, G., and M. Rubin, Uplift hiswry and earthquake recurrence as deduced from marine terraces on Middleton Island, Alaska, Proceedings of Conference VI, Methodology for Identifying Seismic Gaps and Soon-to-Break Gaps, U. S. Geol. Surv. Open File Rep., 78-943, 687-721, 1978.

Ruff, L., and H. Kanamori, Seismicity and the subduction process, Phys. Earth Planet. Inter., 23, 240-252, 1980.

Savage, J. C., and G. Gu, A plate flexure approximation to postseismic and interseismic deformation, J. Geophys. Res., 90. 8570-8580, 1985.

Savage, J. C., and L. M. Hastic, Surface deformation associated with dip-slip faulting, J. Geophys. Res., 71, 4897-4904, 1966.

Scholz, C. H., M. Wyss, and S. W. Smith, Seismic and aseismic slip on the San Andreas fault, J. Geophys. Res., 74, 2049-2069, 1969.

Shimazaki, K., and T. Nakata, Time-predictable recurrence model for large earthquakes, Geophys. Res. Lett., 7, 279-282, 1980.

Stuiver, M., A high-precision calibration of the AD radiocarbon time scale, Radiocarbon, 24, 1-26, 1982.

Taylor, F. W., Coral reefs on tectonic blocks, Tonga island arc, in Proceedings of the Third International Coral Reef Symposium, Miami, Fla, vol. 2, pp. 275-281, Rosenstiel School of Marine and Atmospheric Science, University of Miami, Miami, Fla., 1977.

Taylor, F. W., Quaternary tectonic and sea level history, Tonga and Fiji, Southwest Pacific, Ph. D. dissertation, 355 pp., Cornell Univ., Ithaca, N. Y., May 1978.

Taylor, F. W., B. L. Isacks, C. Jouannic, A. L. Bloom, and J. Dubois, Coseismic and Quaternary vertical tectonic movements, Santo and Malekula islands, New Hebrides island arc, $J$. Geophys. Res., 85, 5367-5381, 1980.

Taylor, F. W., C. Jouannic, L. Gilpin, and A. L. Bloom, Coral colonies as monitors of change in relative level of the land and sea: applications to vertical tectonism, in Proceedings of the Fourth International Coral Reef Symposium, Manila, vol. 2, pp. 485-492, Marine Science Center, University of the Philippines, Quezon City, 1981.

Taylor, F. W., C. Jouannic, and A. L. Bloom, Quaternary uplift history of the Torres Islands, northern New Hebrides frontal arc: Comparison with Santo and Malekula Islands, central New Hebrides frontal arc, J. Geol., 93, 419-438, 1985.

Taylor, F. W., C. Frohlich, J. Lecolle, and M. Strecker, Analysis of partially emerged corals and reef terraces in the central Vanuatu arc: Comparison of contemporary coseismic and nonseismic with Quatemary vertical movements, J. Geophys. Res., 92, 49054933, 1987.

Thom, B. G., and J. Chappell, Holocene sea levels relative to Australia, Search, 6, 90-93, 1975.

Urmos, J., Oxygen isotopes, sea levels, and uplift of reef terraces, Araki Island, Vanuatu, M. S. thesis, 123 pp., Comell Univ. Ithaca, N. Y., 1985.

Uyeda, S. and H. Kanamori, Back-arc opening and the mode of subduction, J. Geophys. Res., 84, 1049-1061, 1979.

Yonekura, N., Quatemary tectonic movements in the outer arc of southwest Japan with special reference to seismic crustal deformations, Bull. Dep. Geogr. Univ. Tokyo, 7, 19-71, 1975. 
R. L. Edwards, Department of Geology and Geophysics, 310 Pillsbury Drive S.E., University of Minnesota, Minneapolis, Minnesota 55455.

C. Frohlich and F. W. Taylor, Institute for Geophysics, The University of Texas at Austin, 8701 MoPac Blvd., Austin, TX 78759.
G. J. Wasserburg, Division of Geological and Planetary Sciences, California Institute of Technology, Pasadena, CA 91125.

Received July 28, 1988;

reevised April 13, 1989;

accepted June 20, 1989.) 